\title{
Prevalence of antibiotic use and household water- sanitation risk factors of acute watery diarrhea among children < 5 years: retrospective analysis of multicounty health survey data, 2006-2018
}

Md. Shakil Ahmed ( $\nabla$ shakil.statru@gmail.com )

University of Rajshahi

\section{Research Article}

Keywords: AWD, Health Survey (DHS), Multiple Indicator Cluster Survey (MICS), Improved as reference category

Posted Date: April 12th, 2021

DOI: https://doi.org/10.21203/rs.3.rs-401478/v1

License: (c) (1) This work is licensed under a Creative Commons Attribution 4.0 International License. Read Full License 


\section{Abstract}

A total 12,69,944 under five year Childs were included in this study among them 1,80,067 Childs were acute watery diarrhea (AWD) and 19,502 Childs were bloody diarrhea respectively. Among them 47,755 Childs were taken antibiotic treatment for AWD. The overall prevalence of acute watery diarrhea 14\% (prevalence $=0.142 ; 95 \% \mathrm{Cl}=0.141,0.142$ ). On the other hand the prevalence of bloody diarrhea $\sim 2 \%$ (prevalence $=0.015 ; 95 \% \mathrm{Cl}=0.015,0.016$ ). The prevalence of antibiotic treatment for AWD was $\sim 27 \%$ (prevalence $=0.27,95 \% \mathrm{Cl}=0.26,0.27$ ) among the under five years old children in $\mathrm{DH}$ survey regions in the world. The prevalence of acute watery diarrhea was higher $\sim 17 \%$ (prevalence $=0.17,95 \% \mathrm{Cl}=0.16$, 0.17 ) in the Latin America DHS survey region. The minimum prevalence of AWD was almost equal between South East Asia and Central Asia DHS survey regions 12\% (prevalence $=0.12,95 \% \mathrm{Cl}=0.11$, 0.12 ) and $\sim 12 \%$ (prevalence $=0.12,95 \% \mathrm{Cl}=0.10,0.13$ ) respectively. On the other hand the prevalence of AWD between Europe and West North and Central Africa DHS survey regions 16\% (prevalence $=0.16$, $95 \% \mathrm{Cl}=0.15,0.16$ ) and $\sim 15 \%$ (prevalence $=0.15,95 \% \mathrm{Cl}=0.14,0.15$ ) correspondingly. In the central Asia of 15,089 under five Childs were included in the survey. Among them 1,748 Childs were AWD and 967 Childs had taken antibiotic treatment for AWD. The highest prevalence of antibiotic use for AWD in Central Asia $~ 55 \%$ (prevalence $=(967 / 1748)=0.55,95 \% \mathrm{Cl}=0.52,0.59)$ and Europe DH survey region $44 \%$ (prevalence $=(5483 / 12502)=0.44,95 \% \mathrm{Cl}=0.43,0.45)$. The lowest prevalence of antibiotic use for under five Child AWD was 23\% (prevalence $=(11918 / 51328)=0.23,95 \% \mathrm{Cl}=0.22,0.24)$ in the DH survey region South East Asia. On the other hand the DH survey region Latin America and West North and Central Africa region the prevalence of antibiotic use for AWD were 30\% (prevalence $=(7887 / 26396)=$ $0.30,95 \% \mathrm{Cl}=0.29,0.31)$ and $\sim 24 \%$ (prevalence $=(21500 / 88093)=0.24,95 \% \mathrm{Cl}=0.23,0.24)$. The South East Asia DH survey region countries DHS 2007 (Bangladesh), DHS 2014 and 2010 (Cambodia), DHS 2017 and 2012 (Indonesia), DHS 2009 (Maldives), DHS 2015-2016 (Myanmar), DHS 2012-2013 (Pakistan), DHS 2017 and 2013 (Philippines), and DHS 2009-2010 (Timor-Leste) were higher risk of AWD for drinking unimproved water sources. The prevalence of antibiotic use for u5c AWD was shown highest prevalence in DHS 2007 ( 44\%), DHS 2012 ( 49\%), DHS 2016 ( 40\%), and DHS 2017 ( 65\%) from DH survey 2006 to 2018 in South East \& Central Asia. The linear trend analysis showed that upward trend for using antibiotic of AWD in the South East \& Central Asia DH survey region.

\section{Introduction}

Diarrhea is the state of loose, liquid, or watery bowel engagements three times or more a day. [1] If it will be continue for a few days for a result creates severe dehydration. Among the low- and middle-income countries diarrhea is one of the foremost causes of antibiotic use for children. On the other hand vaccine may prevent diarrhea infections but they often consumed antibiotic treatment.[2] Of 13\% prevalence for purchasing antibiotics without a prescription, $\sim 2 \%$ were preferred by the regulars and $\sim 11 \%$ were suggested by the pharmacists. [3] Cotrimoxazole was the most commonly prescribed drug (51\%), followed by colistin sulfate $(15.3 \%)$, norfloxacin $(11 \%)$, and nalidixic acid $(0.5 \%)$. The average number of antimicrobials per case of inpatients was higher than outpatients $(1.15$ vs $0.84, p<0.001)$. There was a 
trend toward prescribing norfloxacin in childhood diarrhea. [4] The last 20 years shown that the prevalence of antibiotic resistance has increasing remarkably. [5] It is a serious hazard for health among the global people. [6] The low income and middle income countries are higher threatened than high income countries for depletion of antibiotic, prevalence, and confrontation of antibiotic against the childhood diarrhea or diseases by the record. [7] Aggregate the numbers of peoples for gaining access of antimicrobial resistance not only the formal health care but also increasing the antibiotic treatments by the both formal and informal health care providers. $[8,9]$ Moderately a 3rd of patients admitted to hospital are specified by the antibiotic treatment according to the report by the worldwide Point Prevalence Survey. [10] Around $21 \%$ antibiotic were used by oral pills or syrups and $3 \%$ by injections in the Demographic Health Survey (DHS) and Multiple Indicator Cluster Survey (MICS) data. The proportion of antibiotic treatments $3-78 \%$ for childhood diarrhea episodes among 38 included studies. [11] The main objective of this paper to estimate the prevalence of antibiotic use for acute watery diarrhea of under five children (u5c), and retrospectives analysis of household water sanitation risk factors of DHS multi country survey from 2006-2018.

\section{Methods}

\section{Data sources}

In this paper we used 112 Demographic Health Survey (DHS) data. On period of household surveys mothers were asked detailed questions about management of diarrhea episodes. And those under5children were included whose 2-weeks diarrhea episodes earlier the survey date. Of 112 countries 12,69,944 under five Children (u5c) datasets were collected from Demographic and Health Survey (DHS) programmed surveys from 2006 to 2018 (https://dhsprogram.com/Data/). The cross sectional study design used for the DHS survey data collection. The details sampling strategy and methodology discuss in the DHS website and published reports.

\section{Statistical Analysis Method}

The dataset was collected from Demographic and Health Survey (DHS) programmed from 2006 to 2018 survey year. There were 12,69,944 under five Children suffering from acute watery diarrhea (had diarrhea last 24 hours or last two weeks) were analyzed as a study variable or dependent variable. Also analyzed the prevalence of antibiotic use for under five child acute watery diarrhea. The logistic regression was used to estimate crude odds ratio (COR) of household drinking water (Improved as reference category) sources and sanitation (Improved as reference category) risk factors with $95 \%$ confidence interval. The $p$ value was estimated for prediction of significant risk factors of under-five childhood watery diarrhea. The multiple logistic regression was used to estimate the adjusted odds ratio (AOR) the age in months and sex of the children with $95 \%$ confidence interval. All the statistical analysis implemented using the open sources software R statistical programming language (https://www.r-project.org/). The classification of household sanitation and water risk factors are as follows:

\section{Improved Sanitation Facility Group:}



i. flush - to piped sewer system
ii. flush - to septic tank
iii. flush - to pit latrine
iv. flush - don't know where
v. pit latrine - ventilated improved pit (VIP)
vi. pit latrine - with slab
vii. composting toilet

\section{Unimproved Sanitation Facility Group:}
i. flush - to somewhere else
ii. pit latrine - without slab / open pit
iii. bucket toilet
iv. hanging toilet/latrine
v. other

\section{Improved Drinking Water Sources Group:}

i. piped into dwelling piped to yard/plot

ii. public tap/standpipe

iii. piped to neighbor

iv. tube well or borehole

v. protected well

vi. protected spring

vii. rainwater

viii. tanker truck, cart with small tank

ix. bottled water

\section{Unimproved Drinking Water Sources Group:}

i. unprotected well

ii. unprotected spring

iii. surface water (river/dam/lake/pond/stream/canal/irrigation channel)

iv. other

\section{Results}

Overall Characteristics: A total 12,69,944 under five year Childs were included in this study among them 1,80,067 Childs were acute watery diarrhea (AWD) and 19,502 Childs were bloody diarrhea respectively. 
Among them 47,755 Childs were taken antibiotic treatment for AWD. The overall prevalence of acute watery diarrhea $\sim 14 \%$ (prevalence $=0.142 ; 95 \% \mathrm{Cl}=0.141,0.142$ ). On the other hand the prevalence of bloody diarrhea $\sim 2 \%$ (prevalence $=0.015 ; 95 \% \mathrm{Cl}=0.015,0.016$ ). The prevalence of antibiotic treatment for AWD was $\sim 27 \%$ (prevalence $=0.27,95 \% \mathrm{Cl}=0.26,0.27$ ) among the under five years old children in $\mathrm{DH}$ survey regions in the world.

Socio-economic and Demographic characteristics: The wealth index is a significant measurement of socio-economic status. The median (robust measures of central tendency with $50 \%$ outliers tolerate) prevalence of antibiotic use for acute watery diarrhea (AWD) were almost equal among the poorest ( 22\%) and poorer ( 22\%) group Childs respectively. But among the richest people prevalence of antibiotic use was $\sim 14 \%$ for AWD. Therefore, from the box plot (Figure-1(A)) showed that the prevalence of antibiotic use trend was decreasing from poorest to richest (Supplementary Table-1).

The mother education plays significant roles for under five childhood acute watery diarrhea. The prevalence of AWD among the primary and secondary education child mother were higher $~ 31 \%$ (median) and $\sim 28 \%$ (median) respectively. Comparatively lower prevalence of AWD among the no education child mother group 20\% (median) than the primary and secondary education child mother. However, prevalence of AWD remarkably lowers 2\% among the higher education mother (Figure-1(B) and Supplementary Table-2).

The prevalence of AWD was higher among the age group 6-12 months and 12-18 months 19\% (median) and $\sim 18 \%$ (median) respectively. The very low prevalence of AWD among the age group $42-48$ months and $48-54$ months were $~ 5 \%$ (median) and $\sim 5 \%$ (median) respectively (Supplementary Table-3). From the box plot (Figure-1(C)) showed that the prevalence of AWD was decreasing trend from age group 6-12 months to $48-54$ months.

\section{Prevalence of acute watery diarrhea (AWD):}

The prevalence of acute watery diarrhea was higher $\sim 17 \%$ (prevalence $=0.17,95 \% \mathrm{Cl}=0.16,0.17$ ) in the Latin America DHS survey region. The minimum prevalence of AWD was almost equal between South East Asia and Central Asia DHS survey regions 12\% (prevalence $=0.12,95 \% \mathrm{Cl}=0.11,0.12$ ) and $~ 12 \%$ (prevalence $=0.12,95 \% \mathrm{Cl}=0.10,0.13$ ) respectively. On the other hand the prevalence of AWD between Europe and West North and Central Africa DHS survey regions 16\% (prevalence $=0.16,95 \% \mathrm{Cl}=0.15$, 0.16 ) and $\sim 15 \%$ (prevalence $=0.15,95 \% \mathrm{Cl}=0.14,0.15$ ) correspondingly (Table-1).

South East Asia: In Afghanistan 2015 demographic health survey (DHS) 30,951 Childs were included in this survey. Among them 7990 Childs were AWD. It is the highest prevalence 26\% (prevalence=0.26, 95\% $\mathrm{Cl}=0.25,0.26$ ) in the $\mathrm{DH}$ survey region South East Asia. The DH survey 2012-2013 and 2017-2018 in Pakistan were higher prevalence of AWD 21\% (prevalence $=0.21,95 \% \mathrm{Cl}=0.20,0.22$ ) and $~ 18 \%$ (prevalence $=0.18,95 \% \mathrm{Cl}=0.17,0.18$ ). But the Maldives 2009 and 2016-2017 DH survey showed that the lowest prevalence of AWD 5\% (prevalence $=0.05,95 \% \mathrm{Cl}=0.04,0.06$ ) and $4 \%$ (prevalence $=0.04,95 \%$ 
$\mathrm{Cl}=0.03,0.05)$ respectively (Table-1). The details prevalence of AWD in South Asia was shown in the global mapping Figure-2(A).

Central Asia: The highest prevalence of AWD was 15\% (prevalence $=0.15,95 \% \mathrm{Cl}=0.14,0.16$ ) in Tajikistan DH survey 2012. On the other hand the lowest prevalence of AWD was $\sim 5 \%$ (prevalence $=0.05$, $95 \% \mathrm{Cl}=0.05,0.06$ ) in Kyrgyz Republic DH survey 2012 (Table-1 and Figure 2(B)) in the DH survey region Central Asia.

Europe: In the DH survey 2015-2016 and 2017-2018 in Albania was lowest prevalence of AWD 4\% (prevalence $=0.04,95 \% \mathrm{Cl}=0.03,0.15$ ) and $\sim 5 \%$ (prevalence $=0.05,95 \% \mathrm{Cl}=0.05,0.06)$. The highest prevalence of AWD $31 \%$ (prevalence $=0.31,95 \% \mathrm{Cl}=0.30,0.32$ ) in Yemen $2013 \mathrm{DH}$ survey (Table-1 and Figure-2(C)) in the DH survey region Europe.

Latin America: The demographic and health survey 2008 in Bolivia and 2005-2006 in Haiti were highest prevalence of AWD 25\% (prevalence $=0.25,95 \% \mathrm{Cl}=0.24,0.26$ ) and $\sim 22 \%$ (prevalence $=0.22,95 \% \mathrm{Cl}=0.21$, 0.23 ) respectively. The lowest prevalence of AWD was $\sim 10 \%$ (prevalence $=0.10,95 \% \mathrm{Cl}=0.09,0.11$ ) in Guyana 2009 DH survey in the Latin America region (Tabel-1 and Figure-2(D)).

West North and Central Africa: The lowest prevalence of AWD was $\sim 6 \%$ (prevalence $=0.06,95 \% \mathrm{Cl}=0.06$, 0.07) in Benin 2011-2012 DH survey. The demographic health survey 2006 and 2011 in Uganda and Burundi $2010 \mathrm{DH}$ survey were highest prevalence of AWD 26\% (prevalence $=0.26,95 \% \mathrm{Cl}=0.25,0.27$ ), $\sim 23 \%$ (prevalence $=0.23,95 \% \mathrm{Cl}=0.22,0.24$ ), and $\sim 25 \%$ (prevalence $=0.25,95 \% \mathrm{Cl}=0.24,0.26$ ) respectively (Table-1 and Figure-2(E)) in the West North and Central Africa.

\section{Prevalence of Antibiotic use for AWD:}

In the central Asia of 15,089 under five Childs were included in the survey. Among them 1,748 Childs were AWD and 967 Childs had taken antibiotic treatment for AWD. The highest prevalence of antibiotic use for AWD in Central Asia $~ 55 \%$ (prevalence $=(967 / 1748)=0.55,95 \% \mathrm{Cl}=0.52,0.59)$ and Europe DH survey region $\sim 44 \%$ (prevalence $=(5483 / 12502)=0.44,95 \% \mathrm{Cl}=0.43,0.45)$. The lowest prevalence of antibiotic use for under five Child AWD was $23 \%$ (prevalence $=(11918 / 51328)=0.23,95 \% \mathrm{Cl}=0.22,0.24)$ in the $\mathrm{DH}$ survey region South East Asia. On the other hand the DH survey region Latin America and West North and Central Africa region the prevalence of antibiotic use for AWD were $~ 30 \%$ (prevalence= $(7887 / 26396)=0.30,95 \% \mathrm{Cl}=0.29,0.31)$ and $\sim 24 \%$ (prevalence $=(21500 / 88093)=0.24,95 \% \mathrm{Cl}=0.23,0.24)$ (Table-1).

South East Asia: The demographic health survey 2017-2018 in Pakistan and 2007 in Indonesia were highest prevalence of antibiotic use for AWD in the South East Asia. The estimated prevalence were 47\% (prevalence $=0.47,95 \% \mathrm{Cl}=0.44,0.50$ ) and $\sim 44 \%$ (prevalence $=0.44,95 \% \mathrm{Cl}=0.41,0.46$ ) respectively. The lowest prevalence of antibiotic use for AWD in the Maldives DH survey 2016-2017 was 5\% (prevalence $=0.05,95 \% \mathrm{Cl}=-0.18,0.27$ ) and Timor-Leste DH survey 2009-2010 was $\sim 5 \%$ (prevalence $=0.05$, 
$95 \% \mathrm{Cl}=0.0,0.11)$ respectively (Table-1) and the details prevalence shown in the global mapping Figure$3(\mathrm{~A})$.

Central Asia: In the Central Asia DH survey region more than 40\% prevalence of antibiotic use for AWD. The DH survey 2017 in Tajikistan highest prevalence $\sim 65 \%$ (prevalence $=0.65,95 \% \mathrm{Cl}=0.61,0.69$ ) of antibiotic use for Child AWD in the Central Asia region (Table-1 and Figure-3(B)).

Europe: In the DH survey 2012 in Jordan and 2006 in Azerbaijan were highest prevalence of antibiotic use for AWD 54\% (prevalence $=0.54,95 \% \mathrm{Cl}=0.50,0.57$ ) and $\sim 49 \%$ (prevalence $=0.49,95 \% \mathrm{Cl}=0.40,0.58$ ). On the other hand the lowest prevalence of antibiotic use for AWD 15\% (prevalence $=0.15,95 \% \mathrm{Cl}=-0.01$, 0.30 ) in the Europe DH survey region (Table-1 and Figure-3(C)).

Latin America: The DH survey region Latin America the highest prevalence of antibiotic use for AWD in Guatemala 2014-2015 survey $\sim 42 \%$ (prevalence $=0.42,95 \% \mathrm{Cl}=0.39,0.45$ ). Also in the Bolivia DHS 2008, Peru DHS 2009, Peru DHS 2011, Peru DHS 2012 were high prevalence of antibiotic use for AWD. The estimated prevalence for those DHS countries were $40 \%$ (prevalence $=0.40,95 \% \mathrm{Cl}=0.37,0.43$ ), $\sim 40 \%$ (prevalence $=0.40,95 \% \mathrm{Cl}=0.36,0.44$ ), $39 \%$ (prevalence $=0.39,95 \% \mathrm{Cl}=0.35,0.44$ ), and $\sim 38 \%$ (prevalence $=0.38,95 \% \mathrm{Cl}=0.34,0.43$ ) respectively. The lowest prevalence of antibiotic use for AWD was $\sim 10 \%$ (prevalence $=0.10,95 \% \mathrm{Cl}=0.05,0.15$ ) in Haiti 2012 DHS in the DH survey region Latin America (Table-1 and Figure-3(D)).

West North and Central Africa: The lowest prevalence of antibiotic use for AWD in the DH survey region West North and Central Africa in Burundi DHS 2016-2017 and Zimbabwe DHS 2005-2006 were 6\% (prevalence $=0.06,95 \% \mathrm{Cl}=0.02,0.09$ ) and $\sim 6 \%$ (prevalence $=0.06,95 \% \mathrm{Cl}=-0.02,0.14$ ) respectively. The higher prevalence of antibiotic use for AWD in Congo DHS 2011-2012 and Liberia DHS 2013 were 59\% (prevalence $=0.59,95 \% \mathrm{Cl}=0.56,0.63$ ) and $\sim 59 \%$ (prevalence $=0.59,95 \% \mathrm{Cl}=0.56,0.62$ ) respectively. On the other hand, Sierra Leone DHS 2013 and 2008, DHS 2010 in Tanzania were also higher prevalence of antibiotic use for AWD of under five children. The estimated prevalence were $~ 48 \%$ (prevalence $=0.48,95 \%$ $\mathrm{Cl}=0.44,0.52$ ), 44\% (prevalence $=0.44,95 \% \mathrm{Cl}=0.38,0.50$ ), and $\sim 47 \%$ (prevalence $=0.47,95 \% \mathrm{Cl}=0.43$, 0.52 ) correspondingly (Table-1 and Figure-3(E)).

\section{Household water and sanitation risk factors analysis of under five children AWD:}

The multiple logistic regression was used to estimate the odds ratio for measuring water sanitation risk factors of under five children AWD.

\section{Drinking water sources and sanitation toilet risk factor:}

South East Asia: The South East Asia DH survey region countries DHS 2007 (Bangladesh), DHS 2014 and 2010 (Cambodia), DHS 2017 and 2012 (Indonesia), DHS 2009 (Maldives), DHS 2015-2016 (Myanmar), DHS 2012-2013 (Pakistan), DHS 2017 and 2013 (Philippines), and DHS 2009-2010 (Timor-Leste) were higher risk of AWD for drinking unimproved water sources. 
The DH survey 2007 in Bangladesh was 1.10 times (aOR=1.1, 95\% Cl=1.09, 1.11) higher risk of u5c AWD for using unimproved drinking water sources. The DHS $2014 \sim 1.4$ times (aOR=1.40, 95\% $\mathrm{Cl}=1.39$, 1.42) and $2010 \sim 1.11$ times ( $\mathrm{aOR}=1.11,95 \% \mathrm{Cl}=1.10,1.12$ ) more risk of u5c AWD in Cambodia for using unimproved drinking water sources. Similarly, 1.26 times in DHS 2017 and $~ 1.18$ times in 2012 (Indonesia), 1.65 times in DHS 2009 (Maldives), 1.21 times in DHS 2015-2016 (Myanmar), 1.11 times in DHS 2012-2013 (Pakistan), 1.24 times in DHS 2017 and 1.18 times in 2013 (Philippines), and 1.18 times in DHS 2009-2010 (Timor-Leste) higher risk of u5c AWD due to use unimproved drinking water sources respectively (Table-2 and Supplementary Figure-1 (a)).

Most of the countries in the South East Asia region were higher risk of u5c AWD for using unimproved sanitation toilet. On the other hand, DHS 2015 in Afghanistan, DHS 2015-2016 in Myanmar, and DHS 2016 in Timor-Leste were lower risk of AWD (Table-2 and Supplementary Figure-3(a)).

Central Asia: The DH survey 2012 in the Tajikistan was 1.4 times (aOR=1.14, 95\% $\mathrm{Cl}=1.13,1.15)$ higher risk of u5c AWD for drinking unimproved water sources (Table-2 and Supplementary Figure-1(b)). On the other hand, the DHS 2012 in Tajikistan was $4 \%(a O R=1.04,95 \% \mathrm{Cl}=1.03,1.04)$ more risk of AWD using unimproved sanitation toilet (Table-2 and Supplementary Figure-3(b)).

Europe: The DHS 2010 in Armenia, DHS 2016 in Azerbaijan, and DHS 2008 in Egypt were 2 times $(\mathrm{aOR}=1.90,95 \% \mathrm{Cl}=1.85,1.95), \sim 5$ times $(\mathrm{aOR}=4.54,95 \% \mathrm{Cl}=4.35,4.73)$, and $\sim 1.31$ times $(\mathrm{aOR}=1.31,95 \%$ $\mathrm{Cl}=1.28,1.33$ ) were higher risk of AWD for drinking unimproved water sources (Table-2 and

\section{Supplementary Figure-1(c)) .}

The risk of AWD for using unproved sanitation toilet was higher among Armenia (DHS-2010), Azerbaijan (DHS-2006), and Jordan (DHS-2012). The estimated adjusted odds ratio (aOR) was aOR=2.54 (95\% $\mathrm{Cl}=2.47,2.61)$, aOR=1.42 (95\% $\mathrm{Cl}=1.39,1.46)$, and aOR=1.47 (95\% $\mathrm{Cl}=1.45,1.48)$ respectively (Table-2 and Supplementary Figure-3(c)).

Latin America: The DHS 2008 in Bolivia (aOR=1.69; 95\% Cl=1.67, 1.71), DHS 2010 in Colombia (aOR=1.23; $95 \% \mathrm{Cl}=1.22,1.24)$, DHS 2014-2015 in Guatemala (aOR=1.31; 95\% Cl=1.29, 1.33), DHS 2016$2017(\mathrm{aOR}=1.16 ; 95 \% \mathrm{Cl}=1.29,1.33)$ and DHS $2012(\mathrm{aOR}=1.76 ; 1.71,1.80)$ in Haiti, DHS 2012 (aOR=1.49; 95\% $\mathrm{Cl}=1.45,1.48)$, DHS 2009 (aOR=1.59; 95\% Cl=1.57, 1.61), DHS 2007-2008 (aOR=1.55; 95\% Cl=1.53, 1.57), and DHS 2004-2006 (aOR=1.40; $95 \% \mathrm{Cl}=1.38,1.41$ ) in Peru were highest risk of u5c AWD for drinking unimproved water sources (Table-2 and Supplementary Figure-1(d)).

All the DH survey in the DH survey region in Latin America was higher risk of AWD for using unimproved sanitation toilet. But the DHS 2016-2017 in Haiti was lower risk of AWD (aOR=0.99; 95\% $\mathrm{Cl}=0.99,0.99)$ for using unimproved sanitation toilet (Table-2 and Supplementary Figure-3(d)).

West North and Central Africa: Most of DH survey countries were higher risk of AWD of u5c for using unimproved drinking water sources and unimproved sanitation toilet in the West North and Central Africa 
DH survey regions. The details results were shown in the Table-2 (drinking water sources \& sanitation toilet), Supplementary Figure-2 (drinking water sources) and Supplementary Figure-4 (sanitation toilet).

\section{Trend of Antibiotic use for AWD}

South East \& Central Asia: The prevalence of antibiotic use for u5c AWD was shown highest prevalence in DHS 2007 ( 44\%), DHS 2012 ( 49\%), DHS 2016 ( 40\%), and DHS 2017 ( 65\%) from DH survey 2006 to 2018 in South East \& Central Asia. The linear trend analysis showed that upward trend for using antibiotic of AWD in the South East \& Central Asia DH survey region (Figure-4 (A)).

Europe: The prevalence of antibiotic use for U5c AWD was shown highest prevalence in DHS 2007 ( 50\%), DHS 2012 ( 54\%), DHS 2014 ( 47\%), and DHS 2018 ( 32\%) from DH survey 2006 to 2018 in Europe DH survey region. The linear trend analysis showed that downward trend for using antibiotic of AWD in the Europe DH survey region (Figure-4 (B)).

Latin America: The prevalence of antibiotic use for u5c AWD was shown highest prevalence in DHS 2006 ( 37\%), DHS 2008 ( 40\%), DHS 2009 ( 40\%), and DHS 2015 ( 32\%) from DH survey 2006 to 2018 in Latin America DH survey region. The linear trend analysis showed that downward (decreasing pattern) trend for using antibiotic of AWD in the Latin America DH survey region (Figure-4 (C)).

West North and Central Africa: The prevalence of antibiotic use for u5c AWD was shown highest prevalence in DHS 2008 ( 44\%), DHS 2010 ( 47\%), DHS 2012 ( 59\%), DHS 2013 ( 48\%), and DHS 2018 ( $\sim \%)$ from DH survey 2006 to 2018 in West North and Central Africa DH survey region. The linear trend analysis showed that downward (decreasing pattern) trend for using antibiotic of AWD in the West North and Central Africa DH survey region (Figure-4 (D)).

\section{Discussion And Conclusions}

Antibiotic use for acute watery diarrhea among the under five children are common phenomenon in the low and middle income countries. The overall prevalence of diarrhea among the South East Asia and Central Asia are equally distributed among the under child watery diarrhea. The highest prevalence of antibiotic use of under five children diarrhea among the Central Asia on the other hand the lowest prevalence of antibiotic use among the West North and Central Africa DH survey region. According to the trend analysis shown that the prevalence of antibiotic use for under five children diarrhea was the increasing trend among the South East and Central Asia DH survey regions. However all the other DH survey regions (Europe, Latin America, and West North and Central Africa) were decreasing trend of antibiotic use for under five children diarrhea.

\section{Declarations}

Acknowledgement 
The author is cordially grateful to the DHS for making the data access available for analysis and publications. This work was done by author won interest, there no funding for this study. The authors had full access to all the data in the study and had final responsibility for the decision to submit for publication.

\section{Author contributions}

All the statistical analysis and write \& revised the manuscript and provided important intellectual content. The author approved the final version of the manuscript.

\section{Competing interests}

The author(s) declare no competing interests.

\section{Data Availability}

The study data are available upon request from the Demographic and Health Surveys program (https://dhsprogram.com/).

\section{References}

1. "Diarrhoeal disease Factsheet". World Health Organization. 2 May 2017. Retrieved 29 October2020.

2. Lewnard JA, Rogawski McQuade ET, Platts-Mills JA, Kotloff KL, Laxminarayan R. Incidence and etiology of clinically-attended, antibiotic-treated diarrhea among children under five years of age in low- and middle-income countries: Evidence from the Global Enteric Multicenter Study. PLoS Negl Trop Dis. 2020 Aug 10;14(8):e0008520. doi: 10.1371/journal.pntd.0008520. PMID: 32776938; PMCID: PMC7444547.

3. Ecker L, Ruiz J, Vargas M, Del Valle LJ, Ochoa TJ. Prevalencia de compra sin receta y recomendación de antibióticos para niños menores de 5 años en farmacias privadas de zonas periurbanas en Lima, Perú, Prevalence of purchase of antibiotics without prescription and antibiotic recommendation practices for children under five years of age in private pharmacies in peri-urban areas of Lima, Peru. Rev Peru Med Exp Salud Publica. 2016 Jun;33(2):215-23. Spanish. PMID: 27656919.

4. Howteerakul N, Higginbotham N, Dibley MJ. Antimicrobial use in children under five years with diarrhea in a central region province, Thailand. Southeast Asian J Trop Med Public Health. 2004 Mar;35(1):181-7. PMID: 15272767.

5. Kumarasamy KK, Toleman MA, Walsh TR, et al. Emergence of a new antibiotic resistance mechanism in India, Pakistan, and the UK: a molecular, biological, and epidemiological study. Lancet Infect Dis 2010; 10: 597-602.

6. Klein EY, Van Boeckel TP, Martinez EM, et al. Global increase and geographic convergence in antibiotic consumption between 2000 and 2015. Proc Natl Acad Sci USA 2018; 115: e3463-70. 
7. Klein EY, Tseng KK, Pant S, Laxminarayan R. Tracking global trends in the effectiveness of antibiotic therapy using the Drug Resistance Index. BMJ Glob Health 2019; 4:

8. Olesen SW, Barnett ML, MacFadden DR, Lipsitch M, Grad YH. Trends in outpatient antibiotic use and prescribing practice among US older adults, 2011-15: observational study. BMJ 2018; 362:

9. Nolte 0 . Antimicrobial resistance in the 21 st century: a multifaceted challenge. Protein Pept Lett 2014; 21: 330-35.

10. Versporten A, Zarb P, Caniaux I, et al. Antimicrobial consumption and resistance in adult hospital inpatients in 53 countries: results of an internet-based global point prevalence survey. Lancet Glob Health 2018; 6: e619-29.

11. Sreeramareddy, C., and P. Mittal. "Antibiotic use for childhood diarrhea in low-and-middle-income countries: Re-analyses of survey data and systematic review of literature." International Journal of Infectious Diseases, 101 (2020): 105.

\section{Tables}

Table-1: Prevalence of diarrhea of under-five child (u5c) among 112 DHS national survey 2006-2018 


\begin{tabular}{|c|c|c|c|c|c|}
\hline $\begin{array}{l}\text { DHS Survey } \\
\text { Countries }\end{array}$ & $\begin{array}{l}\text { Total } \\
\text { No. of } \\
\text { u5c }\end{array}$ & $\begin{array}{l}\text { No. of } \\
\text { u5c } \\
\text { diarrhea }\end{array}$ & $\begin{array}{l}\text { Diarrhea } \\
\text { of u } 5 \mathrm{c}\end{array}$ & $\begin{array}{l}\text { No. of u } 5 c \\
\text { antibiotic use for } \\
\text { AWD }\end{array}$ & $\begin{array}{l}\text { Antibiotic } \\
\text { use for } \\
\text { AWD }\end{array}$ \\
\hline South East Asia & $\mathbf{N}$ & $\mathrm{n}$ & $\begin{array}{l}\text { Prevalence } \\
(95 \% \mathrm{Cl})\end{array}$ & $\mathrm{n}$ & $\begin{array}{l}\text { Prevalence } \\
(95 \% \mathrm{Cl})\end{array}$ \\
\hline Afghanistan (2015) & 30951 & 7990 & $\begin{array}{l}0.26(0.25 \\
0.26)\end{array}$ & 1522 & $\begin{array}{l}0.19(0.17 \\
0.21)\end{array}$ \\
\hline Bangladesh (2007) & 5789 & 560 & $\begin{array}{l}0.1(0.09 \\
0.1)\end{array}$ & 56 & $\begin{array}{l}0.1(0.02 \\
0.18)\end{array}$ \\
\hline Cambodia (2014) & 6970 & 855 & $\begin{array}{l}0.12(0.11, \\
0.13)\end{array}$ & 45 & $\begin{array}{l}0.05(-0.01, \\
0.12)\end{array}$ \\
\hline Cambodia (2010) & 7820 & 1135 & $\begin{array}{l}0.15(0.14 \\
0.15)\end{array}$ & 83 & $\begin{array}{l}0.07(0.02 \\
0.13)\end{array}$ \\
\hline India (2015-2016) & 247743 & 22500 & $\begin{array}{l}0.09(0.09 \\
0.09)\end{array}$ & 5464 & $\begin{array}{l}0.24(0.23, \\
0.25)\end{array}$ \\
\hline Indonesia (2017) & 17263 & 2440 & $\begin{array}{l}0.14(0.14, \\
0.15)\end{array}$ & 306 & $\begin{array}{l}0.13(0.09, \\
0.16)\end{array}$ \\
\hline Indonesia (2012) & 17323 & 2505 & $\begin{array}{l}0.14(0.14 \\
0.15)\end{array}$ & 321 & $\begin{array}{l}0.13(0.09 \\
0.16)\end{array}$ \\
\hline Indonesia (2007) & 17891 & 2536 & $\begin{array}{l}0.14(0.14 \\
0.15)\end{array}$ & 1104 & $\begin{array}{l}0.44(0.41 \\
0.46)\end{array}$ \\
\hline $\begin{array}{l}\text { Maldives (2016- } \\
\text { 2017) }\end{array}$ & 3055 & 126 & $\begin{array}{l}0.04(0.03, \\
0.05)\end{array}$ & 6 & $\begin{array}{l}0.05(-0.18, \\
0.27)\end{array}$ \\
\hline Maldives (2009) & 3759 & 188 & $\begin{array}{l}0.05(0.04 \\
0.06)\end{array}$ & 20 & $\begin{array}{l}0.11(-0.04, \\
0.25)\end{array}$ \\
\hline $\begin{array}{l}\text { Myanmar (2015- } \\
\text { 2016) }\end{array}$ & 4596 & 550 & $\begin{array}{l}0.12(0.11, \\
0.13)\end{array}$ & 219 & $\begin{array}{l}0.4(0.33 \\
0.46)\end{array}$ \\
\hline Nepal (2016) & 4861 & 336 & $\begin{array}{l}0.07(0.06 \\
0.08)\end{array}$ & 102 & $\begin{array}{l}0.3(0.21 \\
0.39)\end{array}$ \\
\hline Nepal (2011) & 5054 & 679 & $\begin{array}{l}0.13(0.12, \\
0.14)\end{array}$ & 93 & $\begin{array}{l}0.14(0.07 \\
0.21)\end{array}$ \\
\hline Nepal (2006) & 5457 & 659 & $\begin{array}{l}0.12(0.11 \\
0.13)\end{array}$ & 61 & $\begin{array}{l}0.09(0.02, \\
0.17)\end{array}$ \\
\hline Pakistan (2017-2018) & 11985 & 2107 & $\begin{array}{l}0.18(0.17 \\
0.18)\end{array}$ & 985 & $\begin{array}{l}0.47(0.44 \\
0.5)\end{array}$ \\
\hline Pakistan (2012-2013) & 10935 & 2298 & $\begin{array}{l}0.21(0.2 \\
0.22)\end{array}$ & 829 & $\begin{array}{l}0.36(0.33, \\
0.39)\end{array}$ \\
\hline Philippines (2017) & 10297 & 652 & $\begin{array}{l}0.06(0.06 \\
0.07)\end{array}$ & 171 & $\begin{array}{l}0.26(0.2 \\
0.33)\end{array}$ \\
\hline
\end{tabular}




\begin{tabular}{|c|c|c|c|c|c|}
\hline Philippines (2013) & 7012 & 551 & $\begin{array}{l}0.08(0.07, \\
0.08)\end{array}$ & 194 & $\begin{array}{l}0.35(0.28, \\
0.42)\end{array}$ \\
\hline Philippines (2008) & 6382 & 571 & $\begin{array}{l}0.09(0.08, \\
0.1)\end{array}$ & 139 & $\begin{array}{l}0.24(0.17 \\
0.32)\end{array}$ \\
\hline Timor-Leste (2016) & 6950 & 700 & $\begin{array}{l}0.1(0.09 \\
0.11)\end{array}$ & 124 & $\begin{array}{l}0.18(0.11 \\
0.25)\end{array}$ \\
\hline $\begin{array}{l}\text { Timor-Leste (2009- } \\
\text { 2010) }\end{array}$ & 9294 & 1390 & $\begin{array}{l}0.15(0.14 \\
0.16)\end{array}$ & 74 & $\begin{array}{l}0.05(0, \\
0.11)\end{array}$ \\
\hline Total & 441387 & 51328 & $\begin{array}{l}0.12(0.11, \\
0.12)\end{array}$ & 11918 & $\begin{array}{l}0.23(0.22, \\
0.24)\end{array}$ \\
\hline \multicolumn{6}{|l|}{ Central Asia } \\
\hline $\begin{array}{l}\text { Kyrgyz Republic } \\
(2012)\end{array}$ & 4236 & 223 & $\begin{array}{l}0.05(0.05 \\
0.06)\end{array}$ & 95 & $\begin{array}{l}0.43(0.33 \\
0.53)\end{array}$ \\
\hline Tajikistan (2017) & 6019 & 802 & $\begin{array}{l}0.13(0.12, \\
0.14)\end{array}$ & 519 & $\begin{array}{l}0.65(0.61, \\
0.69)\end{array}$ \\
\hline Tajikistan (2012) & 4834 & 723 & $\begin{array}{l}0.15(0.14, \\
0.16)\end{array}$ & 353 & $\begin{array}{l}0.49(0.44 \\
0.54)\end{array}$ \\
\hline Total & 15089 & 1748 & $\begin{array}{l}0.12(0.10, \\
0.13)\end{array}$ & 967 & $\begin{array}{l}0.55(0.52, \\
0.59)\end{array}$ \\
\hline \multicolumn{6}{|l|}{ Europe } \\
\hline Albania (2017-2018) & 2755 & 149 & $\begin{array}{l}0.05(0.05, \\
0.06)\end{array}$ & 22 & $\begin{array}{l}0.15(-0.01, \\
0.3)\end{array}$ \\
\hline Armenia (2015-2016) & 1709 & 68 & $\begin{array}{l}0.04(0.03, \\
0.05)\end{array}$ & 22 & $\begin{array}{l}0.32(0.12, \\
0.53)\end{array}$ \\
\hline Armenia (2010) & 1450 & 128 & $\begin{array}{l}0.09(0.07 \\
0.1)\end{array}$ & 41 & $\begin{array}{l}0.32(0.17 \\
0.47)\end{array}$ \\
\hline Azerbaijan (2006) & 2196 & 231 & $\begin{array}{l}0.11(0.09, \\
0.12)\end{array}$ & 113 & $\begin{array}{l}0.49(0.4 \\
0.58)\end{array}$ \\
\hline Egypt (2014) & 15465 & 2010 & $\begin{array}{l}0.13(0.12, \\
0.14)\end{array}$ & 949 & $\begin{array}{l}0.47(0.44, \\
0.5)\end{array}$ \\
\hline Egypt (2008) & 10595 & 979 & $\begin{array}{l}0.09(0.09, \\
0.1)\end{array}$ & 390 & $\begin{array}{l}0.4(0.35 \\
0.45)\end{array}$ \\
\hline Jordan (2017-2018) & 10475 & 968 & $\begin{array}{l}0.09(0.09, \\
0.1)\end{array}$ & 312 & $\begin{array}{l}0.32(0.27 \\
0.37)\end{array}$ \\
\hline Jordan (2012) & 10128 & 1540 & $\begin{array}{l}0.15(0.15 \\
0.16)\end{array}$ & 830 & $\begin{array}{l}0.54(0.5 \\
0.57)\end{array}$ \\
\hline Jordan (2007) & 10237 & 1659 & $\begin{array}{l}0.16(0.15 \\
0.17)\end{array}$ & 836 & $\begin{array}{l}0.5(0.47 \\
0.54)\end{array}$ \\
\hline Yemen (2013) & 15326 & 4770 & $\begin{array}{l}0.31(0.3 \\
13 / 29\end{array}$ & 1968 & $0.41(0.39$ \\
\hline
\end{tabular}


Total

80336

12502

$0.16(0.15, \quad 5483$
$0.16)$

$0.44(0.43$,

$0.45)$

\section{Latin America}

Bolivia (2008)

$8193 \quad 2055$

$0.25(0.24, \quad 825$

$0.26)$

$0.4(0.37$

$0.43)$

\begin{tabular}{|c|c|c|c|}
\hline Colombia (2010) & 17443 & 2495 & $\begin{array}{l}0.14(0.14 \\
0.15)\end{array}$ \\
\hline
\end{tabular}

Dominican Republic 3605 (2013)

637

$0.18(0.16, \quad 125$

$0.2(0.13$,

Dominican Republic $10796 \quad 1773$

$0.19)$

0.27 )

(2007)

Guatemala (2014-

2015)

Guyana (2009)

$12068 \quad 2239$

$0.16(0.16, \quad 294$

$0.17(0.12$,

$0.17)$

0.21 )

(haiti (2016-2017)

Haiti (2016-2017)

6120

$0.19(0.18,946$

0.42 (0.39,

0.19)

$0.45)$

$2105 \quad 213$

$0.1(0.09, \quad 36$

0.11 )

0.17 (0.04,

$0.3)$

Haiti (2012)

1235

$0.2(0.19, \quad 202$

0.21 )

$0.16(0.11$,

0.21 )

$6744 \quad 1415$

$0.21(0.2, \quad 141$

$0.1(0.05$,

$0.22)$

0.15 )

\begin{tabular}{|c|c|c|c|c|c|}
\hline Haiti (2005-2006) & 5596 & 1217 & $\begin{array}{l}0.22(0.21 \\
0.23)\end{array}$ & 182 & $\begin{array}{l}0.15(0.1 \\
0.2)\end{array}$ \\
\hline $\begin{array}{l}\text { Honduras (2011- } \\
\text { 2012) }\end{array}$ & 10592 & 1919 & $\begin{array}{l}0.18(0.17 \\
0.19)\end{array}$ & 684 & $\begin{array}{l}0.36(0.32, \\
0.39)\end{array}$ \\
\hline $\begin{array}{l}\text { Honduras (2005- } \\
2006)\end{array}$ & 10506 & 1797 & $\begin{array}{l}0.17(0.16 \\
0.18)\end{array}$ & 360 & $\begin{array}{l}0.2(0.16 \\
0.24)\end{array}$ \\
\hline Peru (2012) & 9445 & 1254 & $\begin{array}{l}0.13(0.13 \\
0.14)\end{array}$ & 479 & $\begin{array}{l}0.38(0.34, \\
0.43)\end{array}$ \\
\hline Peru (2011) & 8950 & 1312 & $\begin{array}{l}0.15(0.14, \\
0.15)\end{array}$ & 518 & $\begin{array}{l}0.39(0.35, \\
0.44)\end{array}$ \\
\hline Peru (2009) & 10041 & 1475 & $\begin{array}{l}0.15(0.14, \\
0.15)\end{array}$ & 586 & $\begin{array}{l}0.4(0.36 \\
0.44)\end{array}$ \\
\hline Peru (2007-2008) & 16730 & 2680 & $\begin{array}{l}0.16(0.15, \\
0.17)\end{array}$ & 980 & $\begin{array}{l}0.37(0.34, \\
0.4)\end{array}$ \\
\hline Peru (2004-2006) & 16730 & 2680 & $\begin{array}{l}0.16(0.15 \\
0.17)\end{array}$ & 980 & $\begin{array}{l}0.37(0.34, \\
0.4)\end{array}$ \\
\hline Total & 155664 & 26396 & $\begin{array}{l}0.17(0.16, \\
0.17)\end{array}$ & 7887 & $\begin{array}{l}0.30(0.29, \\
0.31)\end{array}$ \\
\hline
\end{tabular}


Central Africa

\begin{tabular}{|c|c|c|c|c|c|}
\hline Angola (2015-2016) & 13619 & 1891 & $\begin{array}{l}0.14(0.13 \\
0.14)\end{array}$ & 406 & $\begin{array}{l}0.21(0.17, \\
0.25)\end{array}$ \\
\hline Benin (2017-2018) & 12651 & 1342 & $\begin{array}{l}0.11(0.1 \\
0.11)\end{array}$ & 101 & $\begin{array}{l}0.08(0.02, \\
0.13)\end{array}$ \\
\hline Benin (2011-2012) & 12679 & 816 & $\begin{array}{l}0.06(0.06 \\
0.07)\end{array}$ & 163 & $\begin{array}{l}0.2(0.14 \\
0.26)\end{array}$ \\
\hline Burkina Faso (2010) & 13716 & 2031 & $\begin{array}{l}0.15(0.14 \\
0.15)\end{array}$ & 576 & $\begin{array}{l}0.28(0.25, \\
0.32)\end{array}$ \\
\hline Burundi (2016-2017) & 12472 & 2664 & $\begin{array}{l}0.21(0.21 \\
0.22)\end{array}$ & 151 & $\begin{array}{l}0.06(0.02, \\
0.09)\end{array}$ \\
\hline Burundi (2010) & 7231 & 1787 & $\begin{array}{l}0.25(0.24, \\
0.26)\end{array}$ & 384 & $\begin{array}{l}0.21(0.17, \\
0.26)\end{array}$ \\
\hline Cameroon (2011) & 10713 & 2078 & $\begin{array}{l}0.19(0.19, \\
0.2)\end{array}$ & 372 & $\begin{array}{l}0.18(0.14, \\
0.22)\end{array}$ \\
\hline Chad (2014-2015) & 16837 & 3292 & $\begin{array}{l}0.2(0.19 \\
0.2)\end{array}$ & 474 & $\begin{array}{l}0.14(0.11, \\
0.18)\end{array}$ \\
\hline Comoros (2012) & 3022 & 480 & $\begin{array}{l}0.16(0.15 \\
0.17)\end{array}$ & 91 & $\begin{array}{l}0.19(0.11, \\
0.27)\end{array}$ \\
\hline Congo (2011-2012) & 8857 & 1531 & $\begin{array}{l}0.17(0.16 \\
0.18)\end{array}$ & 908 & $\begin{array}{l}0.59(0.56 \\
0.63)\end{array}$ \\
\hline Congo (2005) & 4435 & 627 & $\begin{array}{l}0.14(0.13 \\
0.15)\end{array}$ & 203 & $\begin{array}{l}0.32(0.26, \\
0.39)\end{array}$ \\
\hline $\begin{array}{l}\text { Congo Democratic } \\
\text { Republic (2013-2014) }\end{array}$ & 17188 & 2818 & $\begin{array}{l}0.16(0.16 \\
0.17)\end{array}$ & 939 & $\begin{array}{l}0.33(0.3 \\
0.36)\end{array}$ \\
\hline $\begin{array}{l}\text { Congo Democratic } \\
\text { Republic (2007) }\end{array}$ & 7987 & 1287 & $\begin{array}{l}0.16(0.15 \\
0.17)\end{array}$ & 336 & $\begin{array}{l}0.26(0.21, \\
0.31)\end{array}$ \\
\hline $\begin{array}{l}\text { Cote d'Ivoire (2011- } \\
\text { 2012) }\end{array}$ & 7052 & 1276 & $\begin{array}{l}0.18(0.17 \\
0.19)\end{array}$ & 163 & $\begin{array}{l}0.13(0.08, \\
0.18)\end{array}$ \\
\hline Eswatini (2006-2007) & 2537 & 347 & $\begin{array}{l}0.14(0.12, \\
0.15)\end{array}$ & 75 & $\begin{array}{l}0.22(0.12, \\
0.31)\end{array}$ \\
\hline Ethiopia (2016) & 10006 & 1090 & $\begin{array}{l}0.11(0.1 \\
0.12)\end{array}$ & 150 & $\begin{array}{l}0.14(0.08, \\
0.19)\end{array}$ \\
\hline Ethiopia (2011) & 10808 & 1620 & $\begin{array}{l}0.15(0.14 \\
0.16)\end{array}$ & 251 & $\begin{array}{l}0.15(0.11, \\
0.2)\end{array}$ \\
\hline Gabon (2012) & 5747 & 981 & $\begin{array}{l}0.17(0.16, \\
0.18)\end{array}$ & 299 & $\begin{array}{l}0.3(0.25 \\
0.36)\end{array}$ \\
\hline Gambia (2013) & 7788 & 1340 & $\begin{array}{l}0.17(0.16 \\
0.18)\end{array}$ & 325 & $\begin{array}{l}0.24(0.2 \\
0.29)\end{array}$ \\
\hline
\end{tabular}




\begin{tabular}{|c|c|c|c|c|c|}
\hline Ghana (2014) & 5593 & 671 & $\begin{array}{l}0.12(0.11 \\
0.13)\end{array}$ & 243 & $\begin{array}{l}0.36(0.3 \\
0.42)\end{array}$ \\
\hline Ghana (2008) & 2794 & 553 & $\begin{array}{l}0.2(0.18 \\
0.21)\end{array}$ & 201 & $\begin{array}{l}0.36(0.3 \\
0.43)\end{array}$ \\
\hline Guinea (2012) & 6396 & 1071 & $\begin{array}{l}0.17(0.16 \\
0.18)\end{array}$ & 226 & $\begin{array}{l}0.21(0.16 \\
0.26)\end{array}$ \\
\hline Kenya (2014) & 20069 & 2953 & $\begin{array}{l}0.15(0.14 \\
0.15)\end{array}$ & 505 & $\begin{array}{l}0.17(0.14, \\
0.2)\end{array}$ \\
\hline Kenya (2008-2009) & 5706 & 946 & $\begin{array}{l}0.17(0.16 \\
0.18)\end{array}$ & 217 & $\begin{array}{l}0.23(0.17 \\
0.29)\end{array}$ \\
\hline Lesotho (2014) & 2915 & 328 & $\begin{array}{l}0.11(0.1 \\
0.12)\end{array}$ & 52 & $\begin{array}{l}0.16(0.06, \\
0.26)\end{array}$ \\
\hline Liberia (2013) & 7058 & 1675 & $\begin{array}{l}0.24(0.23 \\
0.25)\end{array}$ & 989 & $\begin{array}{l}0.59(0.56 \\
0.62)\end{array}$ \\
\hline Liberia (2007) & 5305 & 1072 & $\begin{array}{l}0.2(0.19 \\
0.21)\end{array}$ & 148 & $\begin{array}{l}0.14(0.08, \\
0.19)\end{array}$ \\
\hline $\begin{array}{l}\text { Madagascar (2008- } \\
\text { 2009) }\end{array}$ & 11750 & 1006 & $\begin{array}{l}0.09(0.08 \\
0.09)\end{array}$ & 260 & $\begin{array}{l}0.26(0.2 \\
0.31)\end{array}$ \\
\hline Malawi (2015-2016) & 16462 & 3402 & $\begin{array}{l}0.21(0.2 \\
0.21)\end{array}$ & 979 & $\begin{array}{l}0.29(0.26 \\
0.32)\end{array}$ \\
\hline Malawi (2010) & 18360 & 3105 & $\begin{array}{l}0.17(0.16, \\
0.17)\end{array}$ & 717 & $\begin{array}{l}0.23(0.2, \\
0.26)\end{array}$ \\
\hline Mali (2012-2013) & 9582 & 844 & $\begin{array}{l}0.09(0.08 \\
0.09)\end{array}$ & 140 & $\begin{array}{l}0.17(0.1 \\
0.23)\end{array}$ \\
\hline Mali (2006) & 12388 & 1450 & $\begin{array}{l}0.12(0.11, \\
0.12)\end{array}$ & 335 & $\begin{array}{l}0.23(0.19, \\
0.28)\end{array}$ \\
\hline Mozambique (2011) & 10291 & 1071 & $\begin{array}{l}0.1(0.1 \\
0.11)\end{array}$ & 313 & $\begin{array}{l}0.29(0.24 \\
0.34)\end{array}$ \\
\hline Namibia (2013) & 4805 & 810 & $\begin{array}{l}0.17(0.16 \\
0.18)\end{array}$ & 156 & $\begin{array}{l}0.19(0.13 \\
0.25)\end{array}$ \\
\hline Namibia (2006-2007) & 4841 & 576 & $\begin{array}{l}0.12(0.11, \\
0.13)\end{array}$ & 112 & $\begin{array}{l}0.19(0.12, \\
0.27)\end{array}$ \\
\hline Niger (2012) & 11602 & 1591 & $\begin{array}{l}0.14(0.13 \\
0.14)\end{array}$ & 199 & $\begin{array}{l}0.13(0.08 \\
0.17)\end{array}$ \\
\hline Niger (2006) & 8209 & 1669 & $\begin{array}{l}0.2(0.19 \\
0.21)\end{array}$ & 590 & $\begin{array}{l}0.35(0.31, \\
0.39)\end{array}$ \\
\hline Nigeria (2013) & 28596 & 2968 & $\begin{array}{l}0.1(0.1 \\
0.11)\end{array}$ & 1121 & $\begin{array}{l}0.38(0.35 \\
0.41)\end{array}$ \\
\hline Nigeria (2008) & 25273 & 2645 & $\begin{array}{l}0.1(0.1 \\
0.11)\end{array}$ & 849 & $\begin{array}{l}0.32(0.29, \\
0.35)\end{array}$ \\
\hline
\end{tabular}




\begin{tabular}{|c|c|c|c|c|c|}
\hline Rwanda (2014-2015) & 7556 & 905 & $\begin{array}{l}0.12(0.11 \\
0.13)\end{array}$ & 106 & $\begin{array}{l}0.12(0.06, \\
0.18)\end{array}$ \\
\hline Rwanda (2010) & 8484 & 1109 & $\begin{array}{l}0.13(0.12, \\
0.14)\end{array}$ & 116 & $\begin{array}{l}0.1(0.05 \\
0.16)\end{array}$ \\
\hline $\begin{array}{l}\text { Sao Tome and } \\
\text { Principe (2008-2009) }\end{array}$ & 1851 & 230 & $\begin{array}{l}0.12(0.11 \\
0.14)\end{array}$ & 61 & $\begin{array}{l}0.27(0.15 \\
0.38)\end{array}$ \\
\hline Senegal (2017) & 11605 & 2212 & $\begin{array}{l}0.19(0.18, \\
0.2)\end{array}$ & 336 & $\begin{array}{l}0.15(0.11 \\
0.19)\end{array}$ \\
\hline Senegal (2016) & 6417 & 1062 & $\begin{array}{l}0.17(0.16, \\
0.17)\end{array}$ & 164 & $\begin{array}{l}0.15(0.1 \\
0.21)\end{array}$ \\
\hline Senegal (2015) & 6602 & 1359 & $\begin{array}{l}0.21(0.2 \\
0.22)\end{array}$ & 195 & $\begin{array}{l}0.14(0.09 \\
0.19)\end{array}$ \\
\hline Senegal (2014) & 6526 & 1272 & $\begin{array}{l}0.19(0.19, \\
0.2)\end{array}$ & 186 & $\begin{array}{l}0.15(0.1 \\
0.2)\end{array}$ \\
\hline Senegal (2012-2013) & 6540 & 972 & $\begin{array}{l}0.15(0.14, \\
0.16)\end{array}$ & 201 & $\begin{array}{l}0.21(0.15 \\
0.26)\end{array}$ \\
\hline Senegal (2010-2011) & 11633 & 2196 & $\begin{array}{l}0.19(0.18, \\
0.2)\end{array}$ & 494 & $\begin{array}{l}0.22(0.19, \\
0.26)\end{array}$ \\
\hline Sierra Leone (2013) & 10618 & 1214 & $\begin{array}{l}0.11(0.11, \\
0.12)\end{array}$ & 581 & $\begin{array}{l}0.48(0.44, \\
0.52)\end{array}$ \\
\hline Sierra Leone (2008) & 5043 & 590 & $\begin{array}{l}0.12(0.11, \\
0.13)\end{array}$ & 258 & $\begin{array}{l}0.44(0.38, \\
0.5)\end{array}$ \\
\hline South Africa (2016) & 3413 & 350 & $\begin{array}{l}0.1(0.09 \\
0.11)\end{array}$ & 37 & $\begin{array}{l}0.11(0, \\
0.21)\end{array}$ \\
\hline $\begin{array}{l}\text { Tanzania (2015- } \\
\text { 2016) }\end{array}$ & 9707 & 1125 & $\begin{array}{l}0.12(0.11, \\
0.12)\end{array}$ & 369 & $\begin{array}{l}0.33(0.28, \\
0.38)\end{array}$ \\
\hline Tanzania (2010) & 7526 & 1015 & $\begin{array}{l}0.13(0.13, \\
0.14)\end{array}$ & 478 & $\begin{array}{l}0.47(0.43, \\
0.52)\end{array}$ \\
\hline Togo (2013-2014) & 6530 & 1042 & $\begin{array}{l}0.16(0.15 \\
0.17)\end{array}$ & 251 & $\begin{array}{l}0.24(0.19 \\
0.29)\end{array}$ \\
\hline Uganda (2016) & 14710 & 2923 & $\begin{array}{l}0.2(0.19 \\
0.21)\end{array}$ & 666 & $\begin{array}{l}0.23(0.2 \\
0.26)\end{array}$ \\
\hline Uganda (2011) & 7355 & 1684 & $\begin{array}{l}0.23(0.22, \\
0.24)\end{array}$ & 589 & $\begin{array}{l}0.35(0.31, \\
0.39)\end{array}$ \\
\hline Uganda (2006) & 7593 & 1956 & $\begin{array}{l}0.26(0.25, \\
0.27)\end{array}$ & 579 & $\begin{array}{l}0.3(0.26 \\
0.33)\end{array}$ \\
\hline Zambia (2013-2014) & 12698 & 2045 & $\begin{array}{l}0.16(0.15, \\
0.17)\end{array}$ & 670 & $\begin{array}{l}0.33(0.29 \\
0.36)\end{array}$ \\
\hline Zambia (2007) & 5844 & 909 & $0.16(0.15$ & 221 & 0.24 (0.19, \\
\hline
\end{tabular}




\begin{tabular}{|c|c|c|c|c|c|}
\hline & & & $0.16)$ & & $0.3)$ \\
\hline Zimbabwe (2015) & 5807 & 931 & $\begin{array}{l}0.16(0.15 \\
0.17)\end{array}$ & 72 & $\begin{array}{l}0.08(0.01, \\
0.14)\end{array}$ \\
\hline $\begin{array}{l}\text { Zimbabwe (2010- } \\
\text { 2011) }\end{array}$ & 5203 & 674 & $\begin{array}{l}0.13(0.12, \\
0.14)\end{array}$ & 116 & $\begin{array}{l}0.17(0.1 \\
0.24)\end{array}$ \\
\hline $\begin{array}{l}\text { Zimbabwe (2005- } \\
\text { 2006) }\end{array}$ & 4867 & 614 & $\begin{array}{l}0.13(0.12, \\
0.14)\end{array}$ & 35 & $\begin{array}{l}0.06(-0.02 \\
0.14)\end{array}$ \\
\hline Total & 577468 & 88093 & $\begin{array}{l}0.15(0.14, \\
0.15)\end{array}$ & 21500 & $\begin{array}{l}0.24(0.23, \\
0.24)\end{array}$ \\
\hline Grand Total & 1269944 & 180067 & $\begin{array}{l}0.142 \\
(0.141, \\
0.142)\end{array}$ & 47755 & $\begin{array}{l}0.27(0.26, \\
0.27)\end{array}$ \\
\hline
\end{tabular}

Table-2: Analysis of household water and sanitation risk factors using multiple logistic regression model ofu5c among 112 DHS national surveys 2006-2018 (Improved as reference category) 


\begin{tabular}{|c|c|c|c|c|}
\hline \multirow[b]{2}{*}{ DHS Survey Countries } & \multicolumn{2}{|c|}{ Drinking water sources } & \multicolumn{2}{|c|}{ Sanitation Toilet } \\
\hline & cOR (95\% Cl) & aOR (95\% Cl) & cOR (95\% Cl) & aOR $(95 \% \mathrm{Cl})$ \\
\hline \multicolumn{5}{|l|}{ South East Asia } \\
\hline Afghanistan (2015) & $\begin{array}{l}0.97(0.97 \\
0.97)\end{array}$ & $\begin{array}{l}0.97(0.97 \\
0.97)\end{array}$ & $0.9(0.9,0.9)$ & $0.9(0.9,0.9)$ \\
\hline Bangladesh (2007) & $\begin{array}{l}1.09 \\
1.1)\end{array}$ & $\begin{array}{l}1.1(1.09, \\
1.11)\end{array}$ & $\begin{array}{l}1.12(1.11, \\
1.13)\end{array}$ & $\begin{array}{l}1.12(1.12, \\
1.13)\end{array}$ \\
\hline Cambodia (2014) & $\begin{array}{l}1.39(1.38 \\
1.41)\end{array}$ & $\begin{array}{l}1.4(1.39 \\
1.42)\end{array}$ & $\begin{array}{l}1.41(1.4, \\
1.43)\end{array}$ & $\begin{array}{l}1.42(1.4, \\
1.43)\end{array}$ \\
\hline Cambodia (2010) & $\begin{array}{l}1.11(1.11, \\
1.12)\end{array}$ & $\begin{array}{l}1.11(1.1, \\
1.12)\end{array}$ & $\begin{array}{l}1.47(1.45, \\
1.49)\end{array}$ & $\begin{array}{l}1.47(1.45, \\
1.49)\end{array}$ \\
\hline India (2015-2016) & $\begin{array}{l}0.81 \\
0.81)\end{array}$ & $\begin{array}{l}0.81 \\
0.81)\end{array}$ & $\begin{array}{l}1.12(1.11, \\
1.12)\end{array}$ & $\begin{array}{l}1.12(1.11, \\
1.12)\end{array}$ \\
\hline Indonesia (2017) & $\begin{array}{l}1.26(1.25 \\
1.26)\end{array}$ & $\begin{array}{l}1.26(1.25 \\
1.26)\end{array}$ & $\begin{array}{l}1.41(1.4 \\
1.42)\end{array}$ & $\begin{array}{l}1.41(1.4, \\
1.42)\end{array}$ \\
\hline Indonesia (2012) & $\begin{array}{l}1.17(1.17, \\
1.18)\end{array}$ & $\begin{array}{l}1.18(1.17, \\
1.19)\end{array}$ & $\begin{array}{l}1.18(1.17, \\
1.19)\end{array}$ & $\begin{array}{l}1.17(1.17, \\
1.18)\end{array}$ \\
\hline Indonesia (2007) & $\begin{array}{l}0.7(0.7 \\
0.71)\end{array}$ & $\begin{array}{l}0.7(0.69 \\
0.71)\end{array}$ & $\begin{array}{l}1.17(1.17, \\
1.18)\end{array}$ & $\begin{array}{l}1.17(1.17, \\
1.18)\end{array}$ \\
\hline Maldives (2009) & $\begin{array}{l}1.65(1.62, \\
1.68)\end{array}$ & $\begin{array}{l}1.65(1.61, \\
1.68)\end{array}$ & $\begin{array}{l}1.98(1.93, \\
2.02)\end{array}$ & $\begin{array}{l}1.97(1.93, \\
2.02)\end{array}$ \\
\hline Myanmar (2015-2016) & $\begin{array}{l}1.21(1.19 \\
1.22)\end{array}$ & $\begin{array}{l}1.21(1.19 \\
1.22)\end{array}$ & $0.99(0.99,1)$ & $0.99(0.99,1)$ \\
\hline Nepal (2016) & $\begin{array}{l}1.03(1.02, \\
1.03)\end{array}$ & $\begin{array}{l}1.03(1.02, \\
1.03)\end{array}$ & $\begin{array}{l}1.24(1.23, \\
1.26)\end{array}$ & $\begin{array}{l}1.24(1.23 \\
1.26)\end{array}$ \\
\hline Nepal (2011) & $\begin{array}{l}0.97(0.96, \\
0.97)\end{array}$ & $\begin{array}{l}0.97(0.96 \\
0.97)\end{array}$ & $\begin{array}{l}1.1(1.09 \\
1.11)\end{array}$ & $\begin{array}{l}1.1(1.09 \\
1.11)\end{array}$ \\
\hline Nepal (2006) & $\begin{array}{l}1.09 \text { (1.09, } \\
1.1)\end{array}$ & $\begin{array}{l}1.09 \\
1.1)\end{array}$ & $\begin{array}{l}1.32(1.3 \\
1.34)\end{array}$ & $\begin{array}{l}1.32(1.3 \\
1.34)\end{array}$ \\
\hline Pakistan (2017-2018) & $\begin{array}{l}1.06(1.06 \\
1.07)\end{array}$ & $\begin{array}{l}1.06(1.06 \\
1.07)\end{array}$ & $\begin{array}{l}1.04(1.04 \\
1.05)\end{array}$ & $\begin{array}{l}1.04(1.04 \\
1.05)\end{array}$ \\
\hline Pakistan (2012-2013) & $\begin{array}{l}1.1(1.1 \\
1.11)\end{array}$ & $\begin{array}{l}1.11(1.1, \\
1.11)\end{array}$ & $\begin{array}{l}1.13(1.12, \\
1.13)\end{array}$ & $\begin{array}{l}1.13(1.12, \\
1.13)\end{array}$ \\
\hline Philippines (2017) & $\begin{array}{l}1.24(1.23 \\
1.25)\end{array}$ & $\begin{array}{l}1.24(1.23 \\
1.25)\end{array}$ & $\begin{array}{l}1.22(1.21 \\
1.23)\end{array}$ & $\begin{array}{l}1.22(1.21, \\
1.23)\end{array}$ \\
\hline Philippines (2013) & $\begin{array}{l}1.19(1.18, \\
1.2)\end{array}$ & $\begin{array}{l}1.18(1.17, \\
1.19)\end{array}$ & $\begin{array}{l}1.04(1.04, \\
1.05)\end{array}$ & $\begin{array}{l}1.04(1.03, \\
1.04)\end{array}$ \\
\hline Philippines (2008) & $0.98(0.98$ & $0.98(0.98$ & 1.41 (1.39, & 1.41 (1.39, \\
\hline
\end{tabular}




\begin{tabular}{|c|c|c|c|c|}
\hline & $0.99)$ & $0.99)$ & 1.43) & 1.43) \\
\hline Timor-Leste (2016) & $\begin{array}{l}0.97(0.97 \\
0.97)\end{array}$ & $\begin{array}{l}0.97(0.97 \\
0.97)\end{array}$ & $0.9(0.9,0.9)$ & $0.9(0.9,0.9)$ \\
\hline Timor-Leste (2009-2010) & $\begin{array}{l}1.09(1.08, \\
1.1)\end{array}$ & $\begin{array}{l}1.1(1.09, \\
1.11)\end{array}$ & $\begin{array}{l}1.12(1.11, \\
1.13)\end{array}$ & $\begin{array}{l}1.12(1.12, \\
1.13)\end{array}$ \\
\hline \multicolumn{5}{|l|}{ Central Asia } \\
\hline Kyrgyz Republic (2012) & $\begin{array}{l}0.74(0.73 \\
0.75)\end{array}$ & $\begin{array}{l}0.74(0.73 \\
0.75)\end{array}$ & $\begin{array}{l}0.76(0.75 \\
0.77)\end{array}$ & $\begin{array}{l}0.75(0.74 \\
0.76)\end{array}$ \\
\hline Tajikistan (2017) & $\begin{array}{l}0.83(0.82 \\
0.83)\end{array}$ & $\begin{array}{l}0.82(0.82 \\
0.83)\end{array}$ & $\begin{array}{l}0.79(0.78 \\
0.8)\end{array}$ & $\begin{array}{l}0.79(0.78 \\
0.8)\end{array}$ \\
\hline Tajikistan (2012) & $\begin{array}{l}1.14(1.13, \\
1.15)\end{array}$ & $\begin{array}{l}1.14(1.13, \\
1.15)\end{array}$ & $\begin{array}{l}1.04(1.03 \\
1.04)\end{array}$ & $\begin{array}{l}1.04(1.03 \\
1.04)\end{array}$ \\
\hline \multicolumn{5}{|l|}{ Europe } \\
\hline Albania (2017-2018) & $\begin{array}{l}0.93(0.92, \\
0.94)\end{array}$ & $\begin{array}{l}0.94(0.93 \\
0.94)\end{array}$ & $\begin{array}{l}0.31(0.3 \\
0.32)\end{array}$ & $\begin{array}{l}0.31(0.3 \\
0.32)\end{array}$ \\
\hline Armenia (2015-2016) & $\begin{array}{l}0.93(0.92, \\
0.93)\end{array}$ & $\begin{array}{l}0.93(0.92 \\
0.94)\end{array}$ & $\begin{array}{l}0.93(0.92 \\
0.93)\end{array}$ & $\begin{array}{l}0.93(0.92 \\
0.94)\end{array}$ \\
\hline Armenia (2010) & $\begin{array}{l}1.88 \\
1.93)\end{array}$ & $\begin{array}{l}1.9(1.85, \\
1.95)\end{array}$ & $\begin{array}{l}2.57(2.5 \\
2.65)\end{array}$ & $\begin{array}{l}2.54(2.47 \\
2.61)\end{array}$ \\
\hline Azerbaijan (2006) & $\begin{array}{l}4.46(4.27, \\
4.65)\end{array}$ & $\begin{array}{l}4.54(4.35 \\
4.73)\end{array}$ & $\begin{array}{l}1.43(1.39 \\
1.46)\end{array}$ & $\begin{array}{l}1.42(1.39 \\
1.46)\end{array}$ \\
\hline Egypt (2014) & $\begin{array}{l}0.93(0.92 \\
0.95)\end{array}$ & $\begin{array}{l}0.93(0.92 \\
0.95)\end{array}$ & $\begin{array}{l}0.68(0.66 \\
0.71)\end{array}$ & $\begin{array}{l}0.69(0.66 \\
0.71)\end{array}$ \\
\hline Egypt (2008) & $\begin{array}{l}1.31(1.28, \\
1.33)\end{array}$ & $\begin{array}{l}1.31(1.28 \\
1.33)\end{array}$ & $\begin{array}{l}0.53(0.51, \\
0.55)\end{array}$ & $\begin{array}{l}0.53(0.51 \\
0.55)\end{array}$ \\
\hline Jordan (2017-2018) & $\begin{array}{l}0.75(0.75 \\
0.76)\end{array}$ & $\begin{array}{l}0.76(0.75 \\
0.76)\end{array}$ & $\begin{array}{l}0.81(0.8 \\
0.81)\end{array}$ & $\begin{array}{l}0.8(0.79 \\
0.8)\end{array}$ \\
\hline Jordan (2012) & $\begin{array}{l}0.71(0.7 \\
0.72)\end{array}$ & $\begin{array}{l}0.71(0.71, \\
0.72)\end{array}$ & $\begin{array}{l}1.47(1.46, \\
1.49)\end{array}$ & $\begin{array}{l}1.47(1.45, \\
1.48)\end{array}$ \\
\hline \multicolumn{5}{|l|}{ Latin America } \\
\hline Bolivia (2008) & $\begin{array}{l}1.69(1.67, \\
1.71)\end{array}$ & $\begin{array}{l}1.69(1.67, \\
1.71)\end{array}$ & $\begin{array}{l}1.31(1.3 \\
1.33)\end{array}$ & $\begin{array}{l}1.31(1.3, \\
1.33)\end{array}$ \\
\hline Colombia (2010) & $\begin{array}{l}1.23(1.22, \\
1.23)\end{array}$ & $\begin{array}{l}1.23(1.22, \\
1.24)\end{array}$ & $\begin{array}{l}1.31(1.3, \\
1.33)\end{array}$ & $\begin{array}{l}1.31(1.3 \\
1.33)\end{array}$ \\
\hline Dominican Republic (2013) & $1(1,1)$ & $1(1,1)$ & $\begin{array}{l}1.23(1.22 \\
1.24)\end{array}$ & $\begin{array}{l}1.23(1.22 \\
1.24)\end{array}$ \\
\hline Dominican Republic (2007) & $\begin{array}{l}0.97(0.97 \\
0.97)\end{array}$ & $\begin{array}{l}0.97(0.97 \\
0.97)\end{array}$ & $\begin{array}{l}1.46(1.44, \\
1.47)\end{array}$ & $\begin{array}{l}1.45(1.44, \\
1.47)\end{array}$ \\
\hline
\end{tabular}




\begin{tabular}{|c|c|c|c|c|}
\hline Guatemala (2014-2015) & $\begin{array}{l}1.31(1.29 \\
1.33)\end{array}$ & $\begin{array}{l}1.31(1.29 \\
1.33)\end{array}$ & $\begin{array}{l}1.2(1.19, \\
1.22)\end{array}$ & $\begin{array}{l}1.2(1.19 \\
1.22)\end{array}$ \\
\hline Guyana (2009) & $\begin{array}{l}0.9(0.9 \\
0.91)\end{array}$ & $\begin{array}{l}0.9(0.9 \\
0.91)\end{array}$ & $\begin{array}{l}1.28(1.27 \\
1.29)\end{array}$ & $\begin{array}{l}1.28(1.27, \\
1.29)\end{array}$ \\
\hline Haiti (2016-2017) & $\begin{array}{l}1.16(1.15 \\
1.16)\end{array}$ & $\begin{array}{l}1.16(1.15 \\
1.16)\end{array}$ & $\begin{array}{l}0.99(0.99 \\
0.99)\end{array}$ & $\begin{array}{l}0.99(0.99, \\
0.99)\end{array}$ \\
\hline Haiti (2012) & $\begin{array}{l}1.76(1.71, \\
1.8)\end{array}$ & $\begin{array}{l}1.76(1.71, \\
1.8)\end{array}$ & $\begin{array}{l}1.31(1.29 \\
1.34)\end{array}$ & $\begin{array}{l}1.31(1.29, \\
1.34)\end{array}$ \\
\hline Haiti (2005-2006) & $\begin{array}{l}1.03(1.03, \\
1.03)\end{array}$ & $\begin{array}{l}1.03(1.02, \\
1.03)\end{array}$ & $\begin{array}{l}1.25(1.23 \\
1.26)\end{array}$ & $\begin{array}{l}1.25(1.23, \\
1.26)\end{array}$ \\
\hline Honduras (2011-2012) & $\begin{array}{l}0.98(0.97 \\
0.98)\end{array}$ & $\begin{array}{l}0.98(0.97 \\
0.98)\end{array}$ & $\begin{array}{l}1.07(1.06 \\
1.07)\end{array}$ & $\begin{array}{l}1.07(1.06, \\
1.07)\end{array}$ \\
\hline Honduras (2005-2006) & $\begin{array}{l}1.08(1.07 \\
1.09)\end{array}$ & $\begin{array}{l}1.08(1.07 \\
1.09)\end{array}$ & $\begin{array}{l}1.07(1.06 \\
1.08)\end{array}$ & $\begin{array}{l}1.07(1.06, \\
1.08)\end{array}$ \\
\hline Peru (2012) & $\begin{array}{l}1.46(1.44, \\
1.47)\end{array}$ & $\begin{array}{l}1.46(1.45 \\
1.48)\end{array}$ & $\begin{array}{l}1.21(1.2 \\
1.22)\end{array}$ & $\begin{array}{l}1.21(1.2 \\
1.22)\end{array}$ \\
\hline Peru (2011) & $\begin{array}{l}0.92(0.91, \\
0.92)\end{array}$ & $\begin{array}{l}0.92(0.91 \\
0.92)\end{array}$ & $\begin{array}{l}1.26(1.25 \\
1.27)\end{array}$ & $\begin{array}{l}1.26(1.25, \\
1.27)\end{array}$ \\
\hline Peru (2009) & $\begin{array}{l}1.59(1.57 \\
1.61)\end{array}$ & $\begin{array}{l}1.59(1.57 \\
1.61)\end{array}$ & $\begin{array}{l}1.34(1.32, \\
1.35)\end{array}$ & $\begin{array}{l}1.33(1.32, \\
1.35)\end{array}$ \\
\hline Peru (2007-2008) & $\begin{array}{l}1.56(1.54, \\
1.57)\end{array}$ & $\begin{array}{l}1.55(1.53, \\
1.57)\end{array}$ & $\begin{array}{l}1.16(1.16, \\
1.17)\end{array}$ & $\begin{array}{l}1.17(1.16, \\
1.18)\end{array}$ \\
\hline Peru (2004-2006) & $\begin{array}{l}1.4(1.38 \\
1.41)\end{array}$ & $\begin{array}{l}1.4(1.38 \\
1.41)\end{array}$ & $\begin{array}{l}1.38(1.37 \\
1.4)\end{array}$ & $\begin{array}{l}1.39 \text { (1.37, } \\
1.4)\end{array}$ \\
\hline \multicolumn{5}{|c|}{ West North and Central Africa } \\
\hline Angola (2015-2016) & $\begin{array}{l}1.49(1.48 \\
1.5)\end{array}$ & $\begin{array}{l}1.49(1.48 \\
1.5)\end{array}$ & $\begin{array}{l}1.36(1.35 \\
1.37)\end{array}$ & $\begin{array}{l}1.36(1.35, \\
1.37)\end{array}$ \\
\hline Benin (2017-2018) & $\begin{array}{l}1.49(1.48, \\
1.5)\end{array}$ & $\begin{array}{l}1.49 \text { (1.48, } \\
1.5)\end{array}$ & $\begin{array}{l}1.36(1.35 \\
1.37)\end{array}$ & $\begin{array}{l}1.36(1.35, \\
1.37)\end{array}$ \\
\hline Benin (2011-2012) & $\begin{array}{l}0.91(0.9 \\
0.91)\end{array}$ & $\begin{array}{l}0.9(0.9 \\
0.91)\end{array}$ & $\begin{array}{l}1.15(1.14, \\
1.15)\end{array}$ & $\begin{array}{l}1.15(1.14, \\
1.15)\end{array}$ \\
\hline Burkina Faso (2010) & $\begin{array}{l}1.27(1.26 \\
1.28)\end{array}$ & $\begin{array}{l}1.27(1.26 \\
1.28)\end{array}$ & $\begin{array}{l}1.7(1.68 \\
1.71)\end{array}$ & $\begin{array}{l}1.69(1.68, \\
1.71)\end{array}$ \\
\hline Burundi (2016-2017) & $\begin{array}{l}1.23(1.22 \\
1.24)\end{array}$ & $\begin{array}{l}1.23(1.22 \\
1.24)\end{array}$ & $\begin{array}{l}1.02(1.01 \\
1.02)\end{array}$ & $\begin{array}{l}1.02(1.01, \\
1.02)\end{array}$ \\
\hline Burundi (2010) & $1(1,1)$ & $1(1,1)$ & $\begin{array}{l}0.93(0.93 \\
0.93)\end{array}$ & $\begin{array}{l}0.93(0.93, \\
0.93)\end{array}$ \\
\hline Cameroon (2011) & $\begin{array}{l}1.02(1.02, \\
1.02)\end{array}$ & $\begin{array}{l}1.02(1.02, \\
1.02)\end{array}$ & $\begin{array}{l}1.25(1.24, \\
1.26)\end{array}$ & $\begin{array}{l}1.25(1.24, \\
1.26)\end{array}$ \\
\hline
\end{tabular}




\begin{tabular}{|c|c|c|c|c|}
\hline Chad (2014-2015) & $\begin{array}{l}1.11(1.1 \\
1.12)\end{array}$ & $\begin{array}{l}1.11(1.1 \\
1.12)\end{array}$ & $\begin{array}{l}1.31(1.3 \\
1.33)\end{array}$ & $\begin{array}{l}1.31(1.3 \\
1.33)\end{array}$ \\
\hline Comoros (2012) & $\begin{array}{l}1.28(1.27 \\
1.29)\end{array}$ & $\begin{array}{l}1.28(1.27 \\
1.29)\end{array}$ & $\begin{array}{l}1.41(1.4 \\
1.43)\end{array}$ & $\begin{array}{l}1.41(1.4 \\
1.43)\end{array}$ \\
\hline Congo (2011-2012) & $\begin{array}{l}0.97(0.97 \\
0.98)\end{array}$ & $\begin{array}{l}0.98(0.97 \\
0.98)\end{array}$ & $\begin{array}{l}0.97(0.96 \\
0.97)\end{array}$ & $\begin{array}{l}0.97(0.96, \\
0.97)\end{array}$ \\
\hline Congo (2005) & $\begin{array}{l}0.89(0.88 \\
0.9)\end{array}$ & $\begin{array}{l}0.89(0.88 \\
0.9)\end{array}$ & $\begin{array}{l}0.81(0.8 \\
0.82)\end{array}$ & $\begin{array}{l}0.81(0.8 \\
0.82)\end{array}$ \\
\hline $\begin{array}{l}\text { Congo Democratic Republic } \\
(2013-2014)\end{array}$ & $\begin{array}{l}0.88(0.87 \\
0.88)\end{array}$ & $\begin{array}{l}0.87(0.87 \\
0.88)\end{array}$ & $\begin{array}{l}1.06(1.05 \\
1.06)\end{array}$ & $\begin{array}{l}1.06(1.05, \\
1.06)\end{array}$ \\
\hline $\begin{array}{l}\text { Congo Democratic Republic } \\
(2007)\end{array}$ & $\begin{array}{l}1.19(1.18, \\
1.2)\end{array}$ & $\begin{array}{l}1.19(1.18 \\
1.21)\end{array}$ & $\begin{array}{l}1.35(1.33 \\
1.36)\end{array}$ & $\begin{array}{l}1.34(1.32, \\
1.36)\end{array}$ \\
\hline Cote d'Ivoire (2011-2012) & $\begin{array}{l}0.97(0.97 \\
0.97)\end{array}$ & $\begin{array}{l}0.97(0.97 \\
0.97)\end{array}$ & $\begin{array}{l}1.2(1.19 \\
1.21)\end{array}$ & $\begin{array}{l}1.2(1.19 \\
1.21)\end{array}$ \\
\hline Eswatini (2006-2007) & $\begin{array}{l}1.2(1.19 \\
1.21)\end{array}$ & $\begin{array}{l}1.2(1.19 \\
1.21)\end{array}$ & $\begin{array}{l}1.09(1.08, \\
1.1)\end{array}$ & $\begin{array}{l}1.09(1.08, \\
1.09)\end{array}$ \\
\hline Ethiopia (2016) & $\begin{array}{l}0.98(0.98 \\
0.99)\end{array}$ & $\begin{array}{l}0.99(0.98 \\
0.99)\end{array}$ & $\begin{array}{l}1.06(1.05 \\
1.07)\end{array}$ & $\begin{array}{l}1.07(1.06, \\
1.07)\end{array}$ \\
\hline Ethiopia (2011) & $\begin{array}{l}1.65(1.61 \\
1.69)\end{array}$ & $\begin{array}{l}1.62(1.59, \\
1.66)\end{array}$ & $\begin{array}{l}1.73(1.69 \\
1.77)\end{array}$ & $\begin{array}{l}1.7(1.66 \\
1.75)\end{array}$ \\
\hline Gabon (2012) & $\begin{array}{l}0.99(0.99 \\
0.99)\end{array}$ & $\begin{array}{l}0.99(0.99 \\
0.99)\end{array}$ & $\begin{array}{l}1.2(1.19 \\
1.21)\end{array}$ & $\begin{array}{l}1.2(1.19 \\
1.21)\end{array}$ \\
\hline Gambia (2013) & $\begin{array}{l}1.12(1.11, \\
1.12)\end{array}$ & $\begin{array}{l}1.12(1.11, \\
1.12)\end{array}$ & $\begin{array}{l}1.33(1.32 \\
1.34)\end{array}$ & $\begin{array}{l}1.33(1.32, \\
1.34)\end{array}$ \\
\hline Ghana (2014) & $\begin{array}{l}1.25(1.23 \\
1.26)\end{array}$ & $\begin{array}{l}1.25(1.23 \\
1.26)\end{array}$ & $\begin{array}{l}1.14(1.13 \\
1.15)\end{array}$ & $\begin{array}{l}1.14(1.13, \\
1.15)\end{array}$ \\
\hline Ghana (2008) & $\begin{array}{l}0.97(0.97 \\
0.98)\end{array}$ & $\begin{array}{l}0.98 \text { (0.97, } \\
0.98)\end{array}$ & $\begin{array}{l}0.77(0.76, \\
0.78)\end{array}$ & $\begin{array}{l}0.77(0.76, \\
0.77)\end{array}$ \\
\hline Guinea (2012) & $\begin{array}{l}0.8(0.79 \\
0.81)\end{array}$ & $\begin{array}{l}0.8(0.79 \\
0.81)\end{array}$ & $\begin{array}{l}1.17(1.16 \\
1.19)\end{array}$ & $\begin{array}{l}1.17(1.16, \\
1.19)\end{array}$ \\
\hline Kenya (2014) & $\begin{array}{l}1.27(1.25, \\
1.29)\end{array}$ & $\begin{array}{l}1.27(1.25 \\
1.29)\end{array}$ & $\begin{array}{l}1.29(1.27 \\
1.31)\end{array}$ & $\begin{array}{l}1.29(1.27, \\
1.31)\end{array}$ \\
\hline Kenya (2008-2009) & $\begin{array}{l}1.35(1.33 \\
1.36)\end{array}$ & $\begin{array}{l}1.34(1.33 \\
1.36)\end{array}$ & $\begin{array}{l}1.24(1.23 \\
1.25)\end{array}$ & $\begin{array}{l}1.24(1.23, \\
1.25)\end{array}$ \\
\hline Lesotho (2014) & $\begin{array}{l}1.11(1.11, \\
1.12)\end{array}$ & $\begin{array}{l}1.11(1.11, \\
1.12)\end{array}$ & $\begin{array}{l}1.16(1.15, \\
1.16)\end{array}$ & $\begin{array}{l}1.16(1.15, \\
1.16)\end{array}$ \\
\hline Liberia (2013) & $\begin{array}{l}1.29(1.27 \\
1.3)\end{array}$ & $\begin{array}{l}1.29(1.27 \\
1.31)\end{array}$ & $\begin{array}{l}1.26(1.25 \\
1.28)\end{array}$ & $\begin{array}{l}1.26(1.25, \\
1.28)\end{array}$ \\
\hline Liberia (2007) & $\begin{array}{l}1.17(1.16, \\
1.19)\end{array}$ & $\begin{array}{l}1.17(1.16, \\
1.19)\end{array}$ & $\begin{array}{l}1.22(1.2 \\
1.24)\end{array}$ & $\begin{array}{l}1.22(1.2 \\
1.24)\end{array}$ \\
\hline
\end{tabular}




\begin{tabular}{|c|c|c|c|c|}
\hline Madagascar (2008-2009) & $\begin{array}{l}1.29(1.28 \\
1.31)\end{array}$ & $\begin{array}{l}1.29(1.28 \\
1.31)\end{array}$ & $\begin{array}{l}1.14(1.13 \\
1.15)\end{array}$ & $\begin{array}{l}1.14(1.13, \\
1.15)\end{array}$ \\
\hline Malawi (2015-2016) & $1(1,1)$ & $1(1,1)$ & $\begin{array}{l}1.04(1.03, \\
1.04)\end{array}$ & $\begin{array}{l}1.04(1.03, \\
1.04)\end{array}$ \\
\hline Malawi (2010) & $\begin{array}{l}0.92(0.91, \\
0.92)\end{array}$ & $\begin{array}{l}0.92 \text { (0.91, } \\
0.92)\end{array}$ & $\begin{array}{l}0.87(0.86 \\
0.88)\end{array}$ & $\begin{array}{l}0.87(0.86, \\
0.88)\end{array}$ \\
\hline Mali (2012-2013) & $\begin{array}{l}1.03(1.03, \\
1.03)\end{array}$ & $\begin{array}{l}1.03(1.03, \\
1.03)\end{array}$ & $\begin{array}{l}1.06(1.06 \\
1.07)\end{array}$ & $\begin{array}{l}1.06(1.06, \\
1.06)\end{array}$ \\
\hline Mali (2006) & $\begin{array}{l}1.07(1.07, \\
1.07)\end{array}$ & $\begin{array}{l}1.07(1.07, \\
1.07)\end{array}$ & $\begin{array}{l}1.13(1.12 \\
1.13)\end{array}$ & $\begin{array}{l}1.13(1.12, \\
1.13)\end{array}$ \\
\hline Mozambique (2011) & $\begin{array}{l}0.71(0.71 \\
0.72)\end{array}$ & $\begin{array}{l}0.72(0.71 \\
0.72)\end{array}$ & $\begin{array}{l}0.88(0.88 \\
0.89)\end{array}$ & $\begin{array}{l}0.88(0.87, \\
0.89)\end{array}$ \\
\hline Namibia (2013) & $\begin{array}{l}1.21(1.2 \\
1.21)\end{array}$ & $\begin{array}{l}1.21(1.2 \\
1.21)\end{array}$ & $\begin{array}{l}1.04(1.04 \\
1.05)\end{array}$ & $\begin{array}{l}1.04(1.04, \\
1.05)\end{array}$ \\
\hline Namibia (2006-2007) & $\begin{array}{l}1.01(1.01 \\
1.01)\end{array}$ & $\begin{array}{l}1.01(1.01 \\
1.01)\end{array}$ & $0.99(0.99,1)$ & $1(0.99,1)$ \\
\hline Niger (2012) & $\begin{array}{l}1.37(1.35, \\
1.38)\end{array}$ & $\begin{array}{l}1.37(1.35, \\
1.39)\end{array}$ & $\begin{array}{l}1.58(1.56 \\
1.61)\end{array}$ & $\begin{array}{l}1.59(1.56, \\
1.62)\end{array}$ \\
\hline Niger (2006) & $\begin{array}{l}1.26(1.25, \\
1.28)\end{array}$ & $\begin{array}{l}1.26(1.25, \\
1.28)\end{array}$ & $\begin{array}{l}1.16(1.15, \\
1.17)\end{array}$ & $\begin{array}{l}1.16(1.15, \\
1.17)\end{array}$ \\
\hline Nigeria (2013) & $\begin{array}{l}0.94(0.93, \\
0.94)\end{array}$ & $\begin{array}{l}0.94(0.93, \\
0.94)\end{array}$ & $\begin{array}{l}0.91(0.91 \\
0.92)\end{array}$ & $\begin{array}{l}0.91 \text { ( } 0.91, \\
0.92)\end{array}$ \\
\hline Nigeria (2008) & $\begin{array}{l}1.15(1.14, \\
1.16)\end{array}$ & $\begin{array}{l}1.15(1.14, \\
1.16)\end{array}$ & $\begin{array}{l}1.34(1.33 \\
1.36)\end{array}$ & $\begin{array}{l}1.34(1.33, \\
1.36)\end{array}$ \\
\hline Rwanda (2014-2015) & $\begin{array}{l}1.3(1.29 \\
1.31)\end{array}$ & $\begin{array}{l}1.3(1.29 \\
1.31)\end{array}$ & $\begin{array}{l}1.06(1.05 \\
1.06)\end{array}$ & $\begin{array}{l}1.06(1.05 \\
1.06)\end{array}$ \\
\hline Rwanda (2010) & $\begin{array}{l}1.38(1.38, \\
1.39)\end{array}$ & $\begin{array}{l}1.38(1.37, \\
1.39)\end{array}$ & $\begin{array}{l}1.04(1.04 \\
1.04)\end{array}$ & $\begin{array}{l}1.04(1.04, \\
1.04)\end{array}$ \\
\hline $\begin{array}{l}\text { Sao Tome and Principe (2008- } \\
\text { 2009) }\end{array}$ & $\begin{array}{l}1.05(1.05 \\
1.06)\end{array}$ & $\begin{array}{l}1.06(1.05 \\
1.06)\end{array}$ & $\begin{array}{l}1.43(1.41 \\
1.44)\end{array}$ & $\begin{array}{l}1.43(1.41, \\
1.44)\end{array}$ \\
\hline Senegal (2017) & $\begin{array}{l}1.19(1.18, \\
1.2)\end{array}$ & $\begin{array}{l}1.18(1.17 \\
1.19)\end{array}$ & $\begin{array}{l}1.17(1.16 \\
1.18)\end{array}$ & $\begin{array}{l}1.17(1.16, \\
1.18)\end{array}$ \\
\hline Senegal (2016) & $\begin{array}{l}0.85(0.83, \\
0.86)\end{array}$ & $\begin{array}{l}0.84(0.82, \\
0.85)\end{array}$ & $\begin{array}{l}1.16(1.14 \\
1.18)\end{array}$ & $\begin{array}{l}1.16(1.14, \\
1.18)\end{array}$ \\
\hline Senegal (2015) & $\begin{array}{l}1.05(1.05 \\
1.06)\end{array}$ & $\begin{array}{l}1.05(1.05 \\
1.06)\end{array}$ & $\begin{array}{l}1.08(1.07 \\
1.08)\end{array}$ & $\begin{array}{l}1.08(1.07 \\
1.08)\end{array}$ \\
\hline Senegal (2014) & $\begin{array}{l}1.22(1.21, \\
1.24)\end{array}$ & $\begin{array}{l}1.22(1.21 \\
1.24)\end{array}$ & $\begin{array}{l}1.02(1.02, \\
1.02)\end{array}$ & $\begin{array}{l}1.02(1.02, \\
1.02)\end{array}$ \\
\hline Senegal (2012-2013) & $1.23(1.22$, & $1.23(1.22$ & $1.26(1.25$ & $1.26(1.25$, \\
\hline
\end{tabular}




\begin{tabular}{|c|c|c|c|c|}
\hline & 1.25) & 1.24) & 1.28) & $1.28)$ \\
\hline Senegal (2010-2011) & $\begin{array}{l}1.03(1.03, \\
1.03)\end{array}$ & $\begin{array}{l}1.03(1.03, \\
1.04)\end{array}$ & $\begin{array}{l}0.91(0.91, \\
0.92)\end{array}$ & $\begin{array}{l}0.92(0.91, \\
0.92)\end{array}$ \\
\hline Sierra Leone (2013) & $\begin{array}{l}1.43(1.41 \\
1.45)\end{array}$ & $\begin{array}{l}1.43(1.41, \\
1.45)\end{array}$ & $\begin{array}{l}1.41(1.39, \\
1.43)\end{array}$ & $\begin{array}{l}1.41(1.39, \\
1.42)\end{array}$ \\
\hline Sierra Leone (2008) & $\begin{array}{l}0.96(0.96 \\
0.97)\end{array}$ & $\begin{array}{l}0.96(0.96, \\
0.97)\end{array}$ & $\begin{array}{l}0.91(0.9 \\
0.91)\end{array}$ & $\begin{array}{l}0.91(0.9 \\
0.91)\end{array}$ \\
\hline South Africa (2016) & $\begin{array}{l}1.24(1.23, \\
1.25)\end{array}$ & $\begin{array}{l}1.24(1.23, \\
1.25)\end{array}$ & $\begin{array}{l}1.02(1.02, \\
1.02)\end{array}$ & $\begin{array}{l}1.02(1.02, \\
1.02)\end{array}$ \\
\hline Tanzania (2015-2016) & $\begin{array}{l}1.11(1.1, \\
1.12)\end{array}$ & $\begin{array}{l}1.11(1.11, \\
1.12)\end{array}$ & $\begin{array}{l}1.21(1.19, \\
1.22)\end{array}$ & $\begin{array}{l}1.21(1.2, \\
1.22)\end{array}$ \\
\hline Tanzania (2010) & $\begin{array}{l}1.24(1.22, \\
1.26)\end{array}$ & $\begin{array}{l}1.24(1.23, \\
1.26)\end{array}$ & $\begin{array}{l}1.22(1.2 \\
1.23)\end{array}$ & $\begin{array}{l}1.22(1.2 \\
1.23)\end{array}$ \\
\hline Togo (2013-2014) & $\begin{array}{l}0.95(0.95 \\
0.95)\end{array}$ & $\begin{array}{l}0.95(0.95, \\
0.95)\end{array}$ & $\begin{array}{l}0.87(0.87, \\
0.88)\end{array}$ & $\begin{array}{l}0.87(0.87, \\
0.88)\end{array}$ \\
\hline Uganda (2016) & $\begin{array}{l}1.2(1.19 \\
1.21)\end{array}$ & $\begin{array}{l}1.2(1.19 \\
1.21)\end{array}$ & $\begin{array}{l}0.95(0.94, \\
0.95)\end{array}$ & $\begin{array}{l}0.95(0.94, \\
0.95)\end{array}$ \\
\hline Uganda (2011) & $\begin{array}{l}1.17(1.16, \\
1.18)\end{array}$ & $\begin{array}{l}1.17(1.16, \\
1.18)\end{array}$ & $\begin{array}{l}1.84(1.81, \\
1.87)\end{array}$ & $\begin{array}{l}1.84(1.81, \\
1.87)\end{array}$ \\
\hline Uganda (2006) & $1(1,1)$ & $1(1,1)$ & $\begin{array}{l}1.09 \\
1.1)\end{array}$ & $\begin{array}{l}1.09 \\
1.1)\end{array}$ \\
\hline Zambia (2013-2014) & $\begin{array}{l}1.22(1.21, \\
1.23)\end{array}$ & $\begin{array}{l}1.22(1.2, \\
1.23)\end{array}$ & $\begin{array}{l}1.08(1.08, \\
1.09)\end{array}$ & $\begin{array}{l}1.08(1.08, \\
1.09)\end{array}$ \\
\hline Zambia (2007) & $\begin{array}{l}1.08(1.07, \\
1.08)\end{array}$ & $\begin{array}{l}1.09(1.08, \\
1.09)\end{array}$ & $\begin{array}{l}1.06(1.05 \\
1.07)\end{array}$ & $\begin{array}{l}1.06(1.06, \\
1.07)\end{array}$ \\
\hline Zimbabwe (2015) & $\begin{array}{l}0.9(0.9 \\
0.91)\end{array}$ & $\begin{array}{l}0.9(0.9 \\
0.91)\end{array}$ & $\begin{array}{l}0.97(0.97 \\
0.98)\end{array}$ & $\begin{array}{l}0.97(0.97, \\
0.98)\end{array}$ \\
\hline Zimbabwe (2010-2011) & $\begin{array}{l}0.75(0.74 \\
0.76)\end{array}$ & $\begin{array}{l}0.75(0.74, \\
0.76)\end{array}$ & $\begin{array}{l}0.88(0.87, \\
0.89)\end{array}$ & $\begin{array}{l}0.88(0.87, \\
0.89)\end{array}$ \\
\hline Zimbabwe (2005-2006) & $\begin{array}{l}1.17(1.16, \\
1.18)\end{array}$ & $\begin{array}{l}1.17(1.16, \\
1.18)\end{array}$ & $\begin{array}{l}1.07(1.07, \\
1.08)\end{array}$ & $\begin{array}{l}1.07(1.06, \\
1.08)\end{array}$ \\
\hline
\end{tabular}

\section{Figures}


(A)

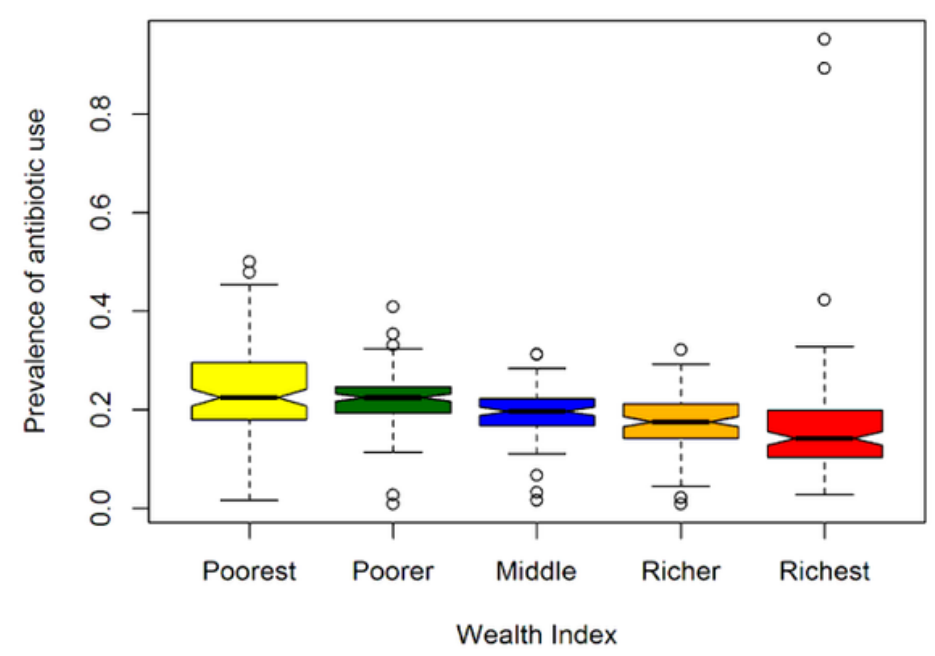

(B) Mother education and diarrhea prevalence

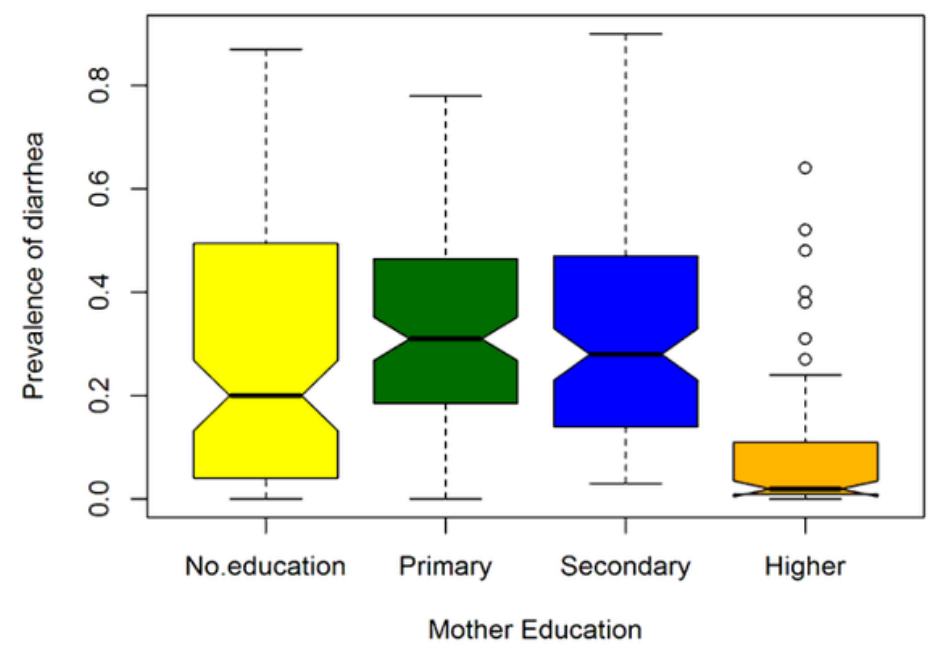

(c) Child age and diarrhea prevalence

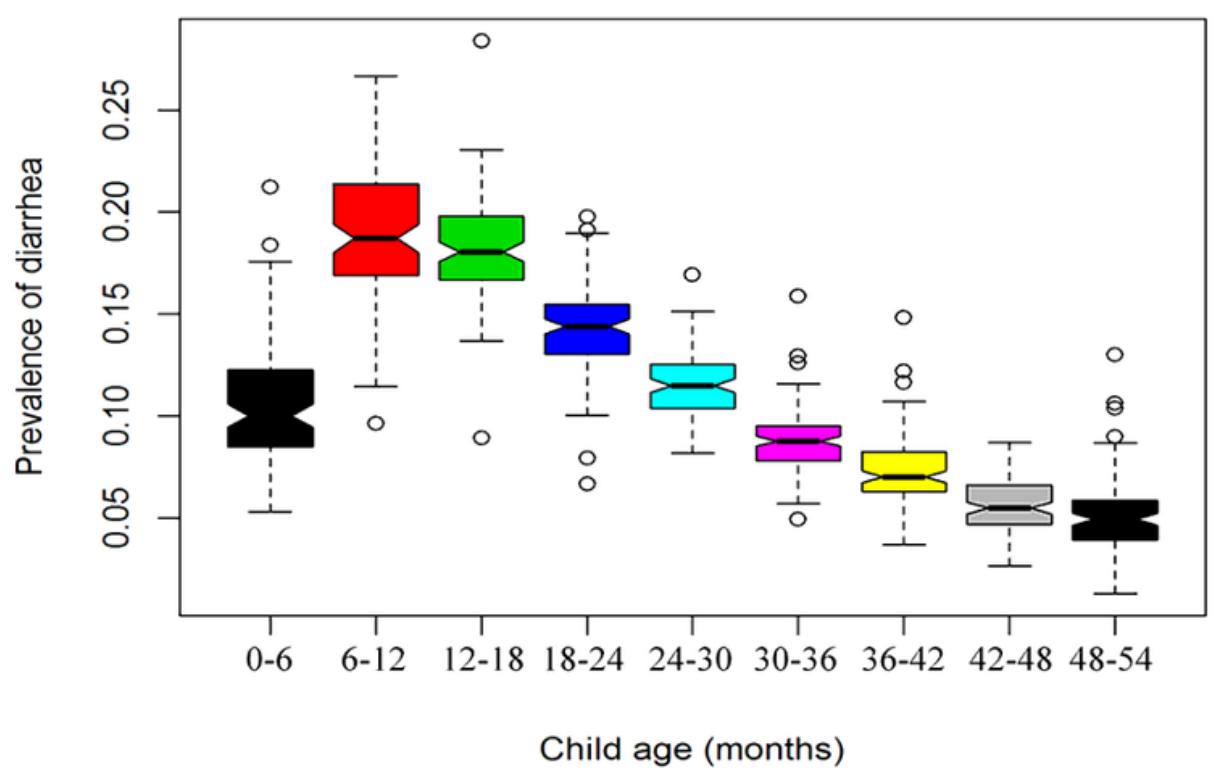

Figure 1

Box plot for (A) prevalence of antibiotic use by wealth index, (B) prevalence of diarrhea by mother education, (C) prevalence of diarrhea at different age groups of several DHS survey regions. 
Prevalence of Diarrhea in South East Asia
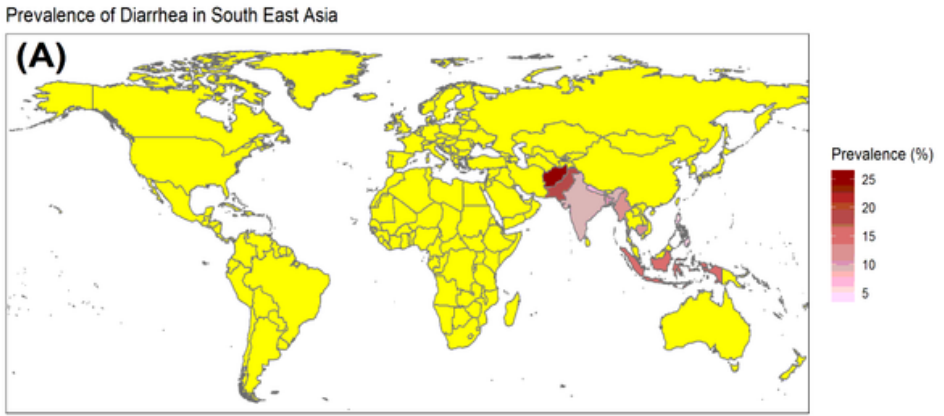

Prevalence of Diarrhea in Europe
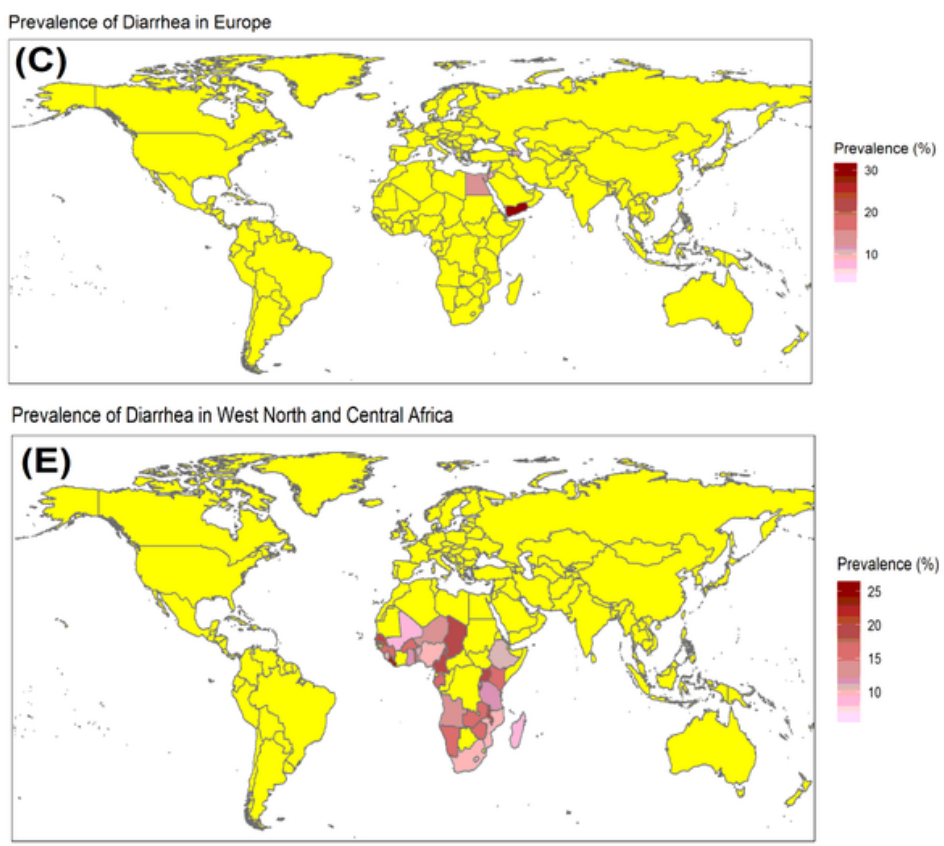

Prevalence of Diarrhea in Central Asia
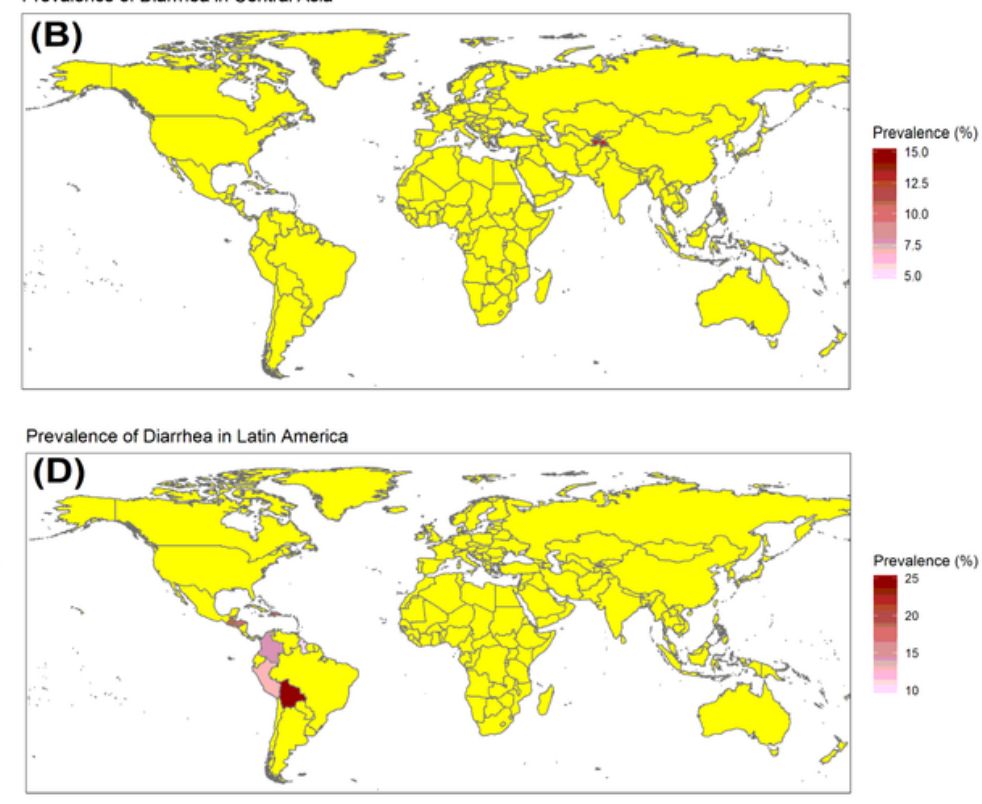

Figure 2

Global mapping of acute watery diarrhea prevalence in different DHS survey regions (A) South East Asia, (B) Central Asia, (C) Europe, (D) Latin America, and (E) North and Central Asia 

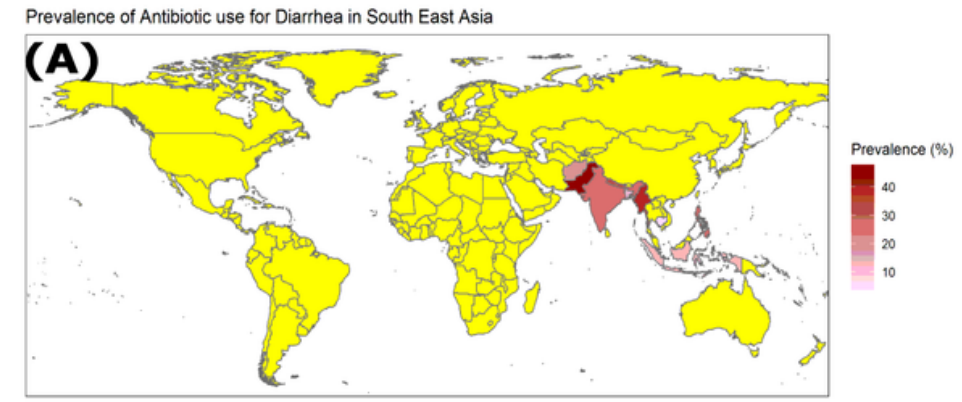

Prevalence of Antibiotic use for Diarrhea in Europe

(C)
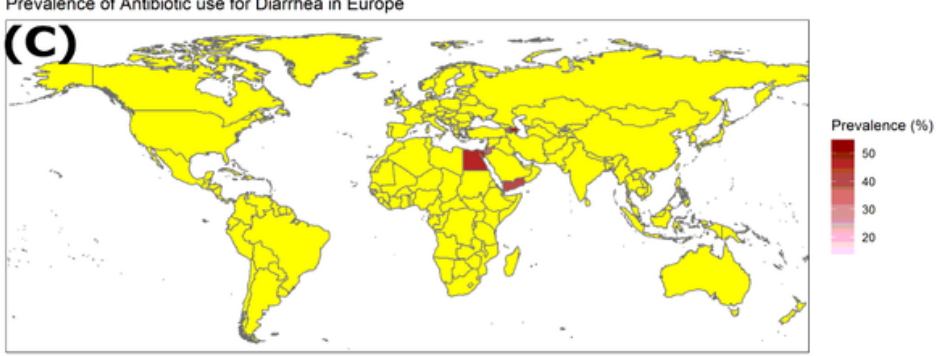

Prevalence of Antibiotic use for Diarrhea in West North and Central Africa

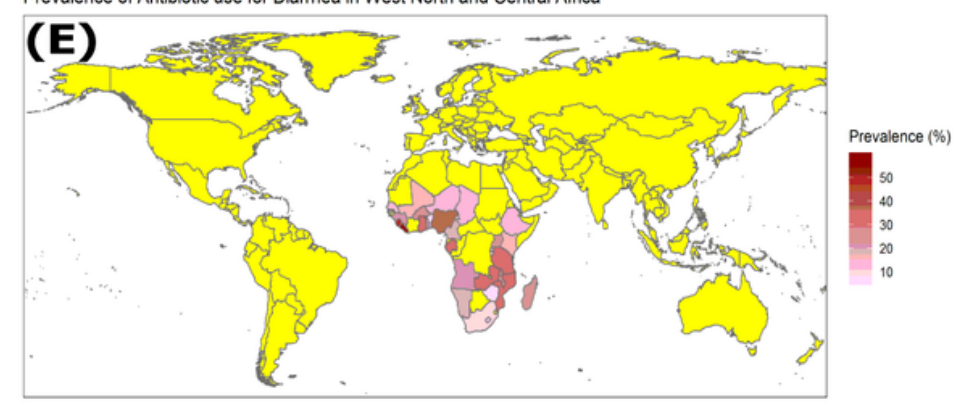

Prevalence of Antibiotic use for Diarrhea in Central Asia

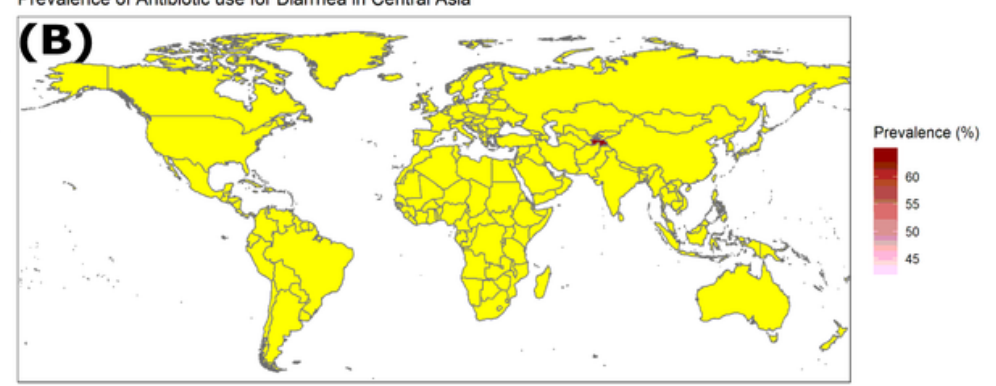

Prevalence of Antibiotic use for Diarrhea in Latin America

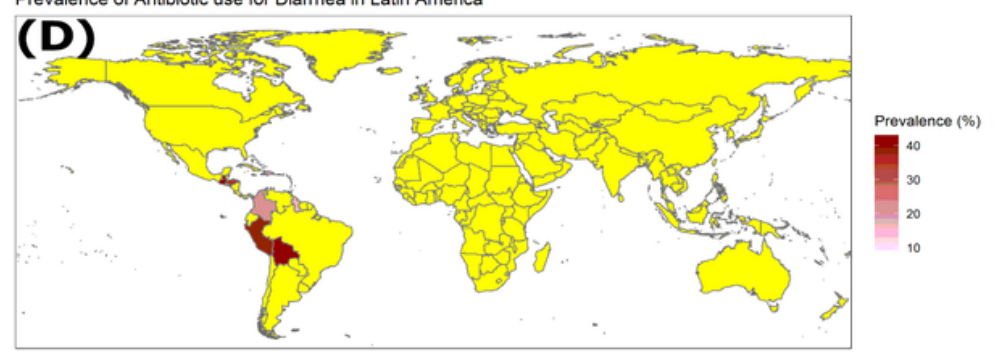

Figure 3

Global mapping of antibiotic treatment prevalence for acute watery diarrhea in different DHS survey regions (A) South East Asia, (B) Central Asia, (C) Europe, (D) Latin America, and (E) North and Central Asia 

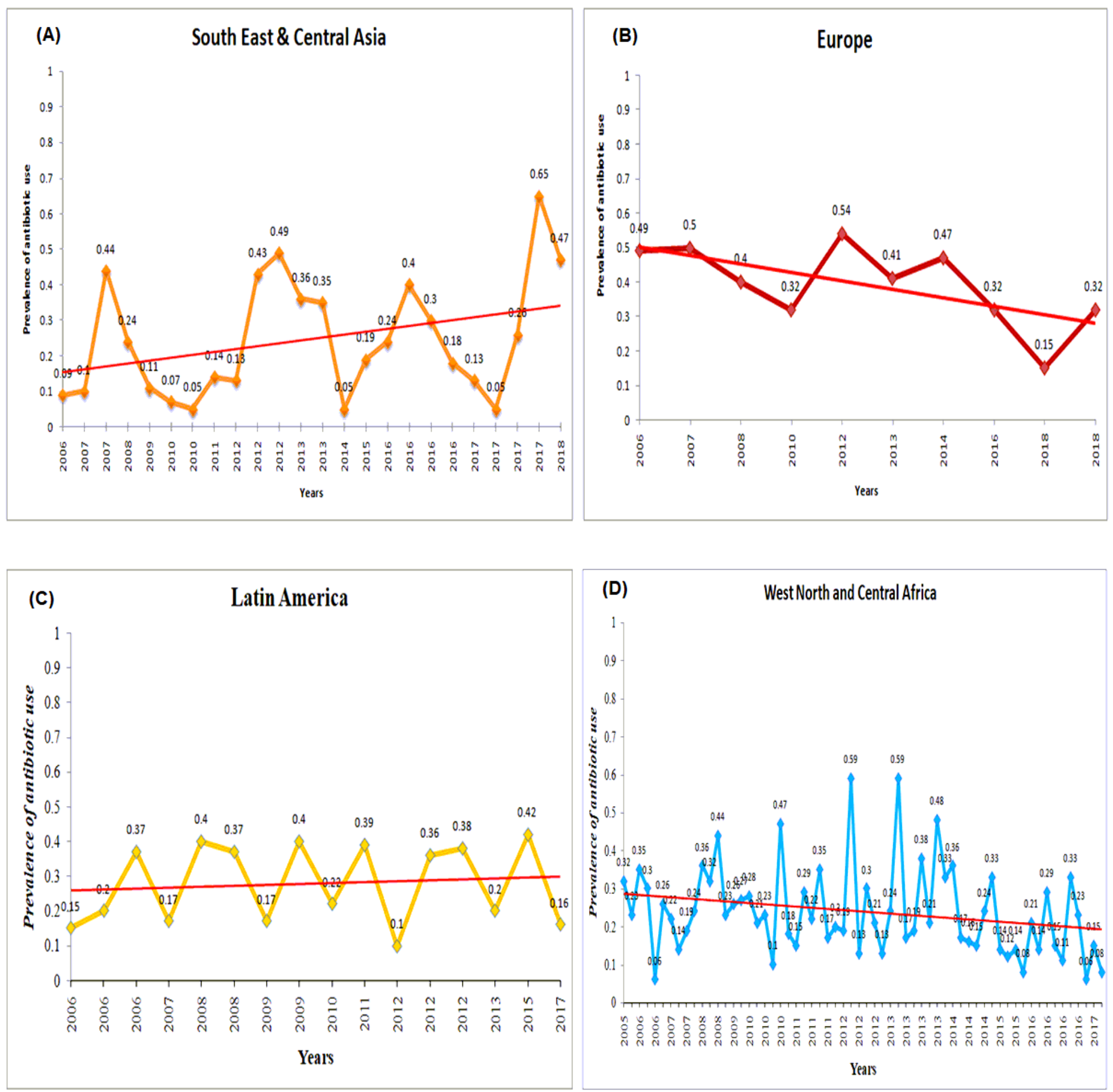

\section{Figure 4}

Linear trend analysis of antibiotic use for AWD among (A) South East and Central Asia, (B) Europe, (C) Latin America, and (D) West North and Central Africa

\section{Supplementary Files}

This is a list of supplementary files associated with this preprint. Click to download. 
- SuplementaryMaterials.docx

Page 29/29 